Review

\title{
Current advances in 3D bioprinting for cancer modeling and personalized medicine
}

\author{
Nicolas Germain 1,2,*,t, Melanie Dhayer ${ }^{1,+}$, Salim Dekiouk ${ }^{1}$ and Philippe Marchetti 1,2,* \\ 1 UMR 9020-UMR-S 1277-Canther-Cancer Heterogeneity, Plasticity and Resistance to Therapies,Institut de \\ Recherche Contre le Cancer de Lille, University Lille, CNRS, Inserm, CHU Lille,F-59000 Lille, France \\ 2 Banque de Tissus, Centre de Biologie-Pathologie, CHU Lille, F-59000 Lille, France \\ * Correspondence: nicolas.germain@inserm.fr (N.G.); philippe.marchetti@inserm.fr (P.M.);Tel.:+33-3-20-16-92- \\ 20 (P.M.) \\ + NG and MD share co-authorship of this manuscript.
}

\begin{abstract}
Tumor cells evolve in a complex and heterogeneous environment composed of different cell types and an extracellular matrix. Current 2D culture methods are very limited in their ability to mimic the cancer cell environment. In recent years, various 3D models of cancer cells have been developed, notably in the form of spheroids/organoids, using scaffold or cancer-on-chip devices. However, these models have the disadvantage of not being able to precisely control the organization of multiple cell types in complex architecture and are sometimes not very reproducible in their production, and this is especially true for spheroids. Three-dimensional bioprinting can produce complex, multi-cellular, and reproducible constructs in which the matrix composition and rigidity can be adapted locally or globally to the tumor model studied. For these reasons, 3D bioprinting seems to be the technique of choice to mimic the tumor microenvironment in vivo as closely as possible. In this review, we discuss different 3D-bioprinting technologies, including bioinks and crosslinkers that can be used for in vitro cancer models, and the techniques used to study cells grown in hydrogels; finally, we provide some applications of bioprinted cancer models.
\end{abstract}

Keywords: 3D bioprinting; 3D printing; bioink; cancer; cell biology

\section{3D bioprinting at a glance}

a. Introduction

Additive manufacturing has been a major breakthrough in construction technologies and has been considered as "the third industrial revolution" [1]. Additive manufacturing, commonly known as 3D printing, allows for building parts one layer at a time from a 3D computer model, allowing for rapid design optimization and customization. Because of these interesting properties, medical applications were quickly developed: 3D-printed prostheses, implants, anatomical models, etc. [2,3]. The ease of use and speed of prototyping even allowed to quickly respond to medical needs during the COVID-19 pandemic [4].

The rapid development of this technology has required the development of new materials capable of being printed, in particular plastics but also metal, ceramic, and elastomers. Traditionally, the materials used for 3D printing in medicine are made of inert and acellular materials such as plastics [5]. Among those materials, some are bio-compatible and can thus be used for implantation [6]; other materials are degradable and are used as guides for soft tissue reconstruction, e.g., breast reconstruction after cancer surgery [7]. Recently, a new field of research in 3D printing has emerged: 3D bioprinting. Three-dimensional bioprinting uses 3D-printing technology to print cells and supportive matrix (called bioink) altogether, ultimately printing a living tissue [8]. Bioinks have been defined by Groll et al. as "a formulation of cells suitable for processing by an automated biofabrication technology that may also contain biologically active components and biomaterials" 
that could be resumed as cell-containing materials [9]. Three-dimensional bioprinting, while promising, raises a large number of concerns and challenges, in particular, the development of biocompatible bioinks and their integration into the human body; however, it seems to be a proper tool for complex tissue in in vitro modeling [10]. Although bioprinting is mainly used for tissue engineering, it seems to us that this technology also has its place in research teams wishing to model the complexity of the cancer microenvironment: its heterogeneity, its mechanical environment, its metabolism, as well as neoangiogenesis, all of which can, of course, be used for drug-screening purposes.

In this review, we will try to propose an easy approach that allows the implementation of bioprinting in a research team, and more particularly in the context of cancer modeling. We will first summarize the main technical features necessary for the implementation of bioprinting: the choice of the bioprinter, the choice of the bioink, and the polymerization method. Secondly, we will detail how bioprinting allows us to refine cancer research, notably by adding a cellular and mechanical complexity that 2D culture cannot provide. The aim is not to be exhaustive, but rather to be comprehensive.

\section{b. Bioprinting technologies}

The first bioprinting technique was described in 2003 by Boland et al., who used an inkjet-based technique to print 2D tissue constructs [11]. Since this first experiment, numerous bioprinting technologies have been created and can be classified into three main categories depending on the type of cell deposition: drop-based (e.g., inkjet or laser bioprinting), filament-based (e.g., extrusion bioprinting), and plane-based (e.g., digital light processing (DLP)/stereolithography (SLA) bioprinting) (Table 1).

Nowadays, the most-used technology is the filament-based one, with different extrusion mechanisms: pneumatic, piston, and screw-driving (Figure 1). Extrusion-based techniques resulting in filament deposition are nowadays the most used as they can quickly produce scaffolds of a resolution down to $100 \odot \mathrm{m}$ in an affordable and relatively simple way.

In our opinion, nowadays, this technology is the easiest to implement; many manufacturers offer machines with multiple extrusion printheads (some printheads may even use inkjet-based printing techniques (see below for detail)) all in a tabletop format, with a user-friendly interface all at reasonable prices. This technology is also compatible with almost all bioink formulations.

Droplet-based techniques are consistent with the discontinuous printing of microdroplets and thus a high resolution. Inkjet printing is the most common technology used for droplet generation and consists of a piezoelectric or thermal actuator that allows the precise deposition of the droplets down to 50॰m. Laser-based droplet deposition allows single-cell deposition, and as a non-contact method, is responsible for low shear stress and thus excellent viability; the drawback is the expensive price of this type of $3 \mathrm{D}$ printer. There are also other less-used approaches, such as acoustic- or valve-based droplet bioprinting technologies. Even if the droplet generation (surface tension) and breaking combined with the force with which it will be projected onto the printing plate can reduce cell viability, drop-based approaches allow higher cell viability than filament-based ones $(>85 \%)$.

This technology, although it brings a precision that extrusion-based cannot have, only allows the printing of 2D patterns. This can be useful to precisely include cells in a pre-existing 3D matrix but not for large-scale constructions.

Plane-based 3D printing is mainly consistent in DLP and SLA technology. In SLA technology, photopolymerization is achieved through a laser beam scanning the surface of a liquid bioink, whereas, in the DLP technique, polymerization is achieved by a digital micromirror device (DMD) or by a liquid crystal display (LCD) [12]. Those techniques have a high resolution down to 25॰m and speed in producing large and complex volumes; however, this technique requires a large volume of bioink, a significant part of which will not be polymerized. 
Despite these interesting characteristics, particularly the speed of printing large volumes and the precision, it is not the easiest to implement this technology, particularly because of the lack of compatible bioinks and its running cost. It is, however, interesting for printing complex microfluidic structures.
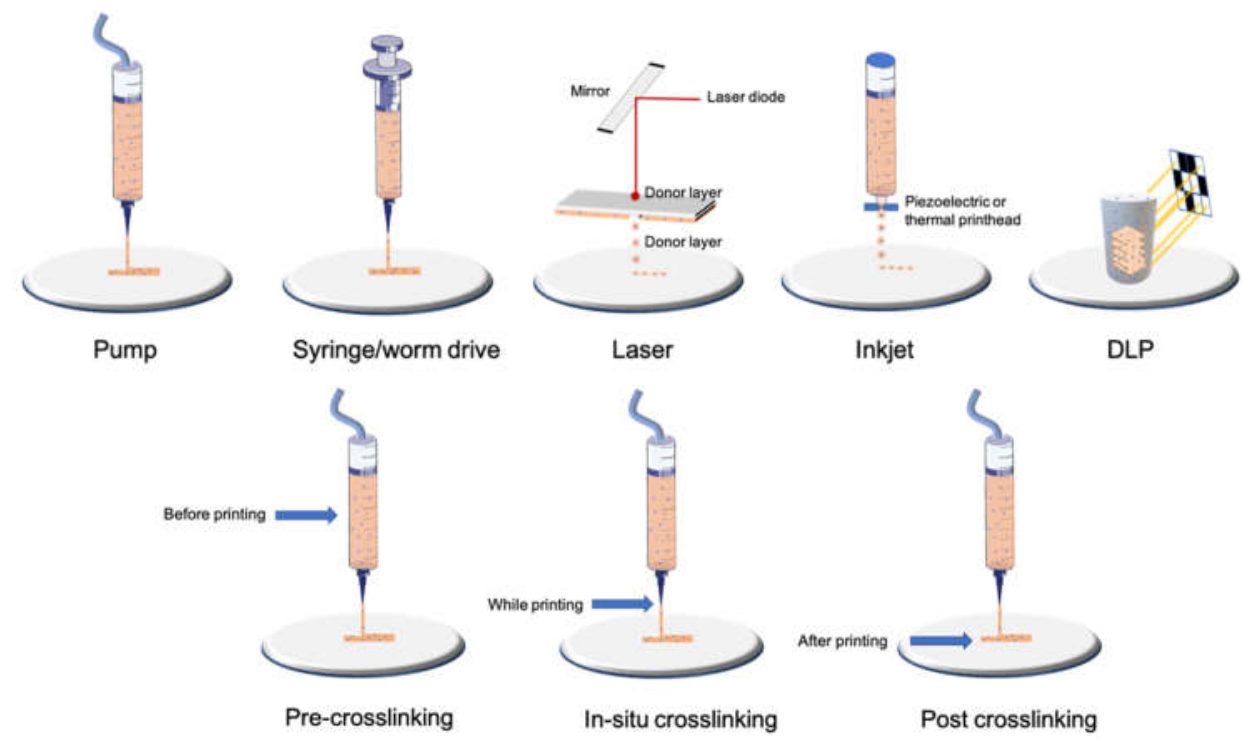

Figure 1. Examples of bioprinting and crosslinking technologies.

\section{c. Bioprinting technologies}

As described above, bioinks are a blend of biomaterial (mainly hydrogels) and cells (Table 2). Properties of such biomaterial are thus critical to their printability and the cells' biological requirements. Biomaterials can be separated into two categories, those derived from naturally occurring products and those of synthetic origin [13]. Their mechanical properties and biodegradation should be carefully assessed to assure (i) printability that will assure easy printing and high shape fidelity (ii) while not inducing cell death during the printing phase and (iii) assuring a construct with the desired mechanical strength (iv), with long-term biocompatibility once printed [14,15]. Using a biomaterial with minimal batch-to-batch variation is also essential to have reproducible 3D constructions. Hydrogels, which are mainly composed of water, are thus the most adapted bioinks as they show a good capability to mimic the natural cell environment combined with good biodegradability and printability [16]. As reported above, the two categories, natural and synthetic, show different properties; natural hydrogels show limited mechanical strength and are subject to rapid degradation, whereas synthetic biomaterials show poor biocompatibility but good mechanical properties and printability. Hence, some authors mix the two to obtain a "hybrid bioink".

The choice of bioink is therefore based on (i) the choice of bioprinting technology, (ii) the characteristics (stiffness, microenvironment) of the tissue to mimic, (iii) the need for a shape fidelity and (iv) the crosslinking technology available. To facilitate the choice of the bioink, a table summarizing the main bioinks and their characteristics is provided (Table 2).

\section{d. Crosslinking}

One of the key steps in the bioprinting process is the crosslinking procedure, as it plays a crucial role in the stabilization of the $3 \mathrm{D}$ construct and thus in cell viability (for review, see [17]). Crosslinking results in chemical and physical modification of the bioinks that will ensure the stability of the different printed layers altogether. Depending on the 
bioink nature, crosslinking can be achieved through enzymatic (e.g., fibrinogen thrombin with fibrin-based bioinks), ionic (e.g., $\mathrm{CaCl} 2$ with alginate), chemical (e.g., horseradish peroxidase and alginate), physical (e.g., UV with gelatin methacrylate), and thermal processes (e.g., gelatin). Crosslinking can be achieved before printing, during the printing process, or after printing (Figure 1).

As with bioinks, the choice of crosslinking method will mainly be based on: (i) the different crosslinking methods available for the bioink chosen, (ii) the necessity of high cell viability after printing (UV light, for example, is widely spread as a crosslinker but can induce DNA damage resulting directly from light radiation, but which may also be related to toxicity linked to the photoinitiator) and (iii) the need for constant mechanical properties over time.

As briefly reported above, there are numerous bioprinting technologies, many biomaterials that can be turned into bioinks, and there are many ways to crosslink, which result in a large number of possibilities. Those many possibilities are a strength on the one hand, as it is, therefore, a tunable technology but, on the other hand, require a detailed protocol to obtain a satisfactory result. Moreover, despite many publications concerning bioprinting, few protocols are sufficiently detailed to be properly reproduced. We, therefore, propose a process flow applicable to all filament-based bioprinting with the main parameters to be taken into account and the cell parameters to be assessed at each stage (Figure 2). Bioprinting is, however, a major breakthrough in tissue engineering and in vitro complex modeling and appears to be a tool of choice for the study of cancer, as will be described in the following paragraphs. We will first describe how to analyze bioprinted constructs and then detail why this technology seems particularly adapted to the study of cancer. 


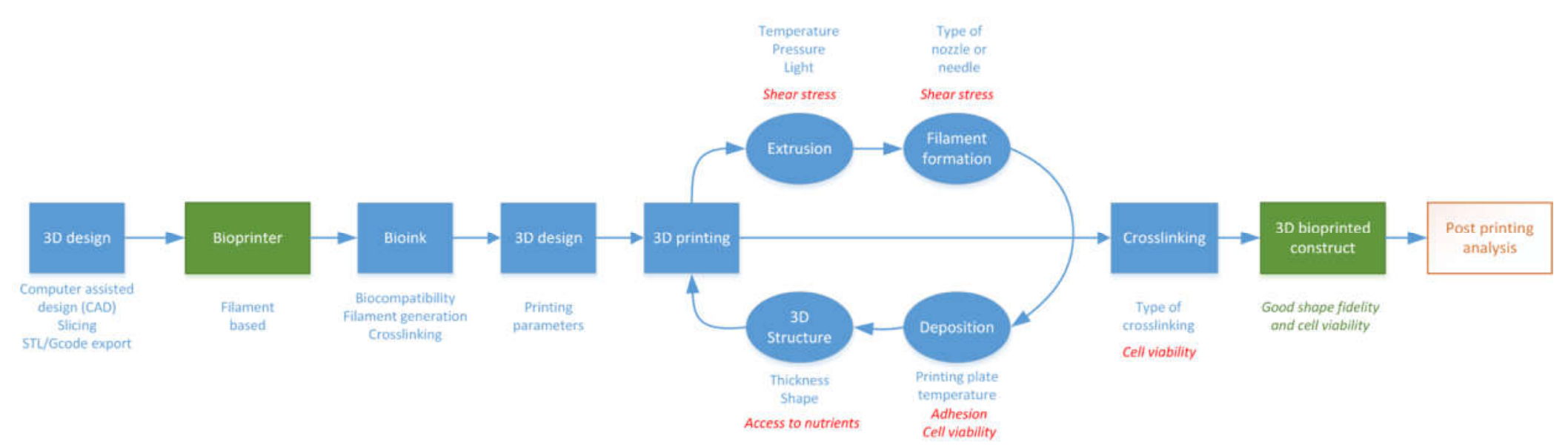

Figure 2. Flow chart proposal for the implementation of 3D filament-based bioprinting. Blue-key technical steps; red -influence of technical choices on cell status.

\begin{tabular}{|c|c|c|c|c|c|c|}
\hline Type of technology & $\begin{array}{l}\text { Example of printing } \\
\text { method }\end{array}$ & Advantages & Disadvantages & Cell density & $\begin{array}{l}\text { Average cell } \\
\text { viability }\end{array}$ & Crosslinking \\
\hline \multirow[t]{4}{*}{ Droplet-based } & Laser & Very high accuracy and resolution & \multirow{4}{*}{$\begin{array}{l}\text { Only low-viscosity bioinks } \\
\text { Only 2D patterns (limited high) }\end{array}$} & \multirow{4}{*}{$\begin{array}{l}\text { Low (less than } 10 \\
\text { million per } \mathrm{mL} \text { ) }\end{array}$} & \multirow{4}{*}{ High } & \multirow{4}{*}{$\begin{array}{l}\text { Depends on } \\
\text { biomaterial } \\
\text { used }\end{array}$} \\
\hline & & Low shear stress & & & & \\
\hline & Inkjet & High accuracy & & & & \\
\hline & & Low shear stress & & & & \\
\hline \multirow[t]{3}{*}{ Filament-based } & Worm drive & \multirow{3}{*}{$\begin{array}{l}\text { Large panel of bioinks available } \\
\text { Low cost } \\
\text { Highly tunable }\end{array}$} & \multirow{3}{*}{$\begin{array}{l}\text { Higher shear stress and lower } \\
\text { cell viability than other } \\
\text { bioprinting technologies }\end{array}$} & \multirow{3}{*}{$\begin{array}{l}\text { High (more than } 10 \\
\text { million per } \mathrm{mL} \text { ) }\end{array}$} & \multirow{3}{*}{$\begin{array}{l}\text { Medium/high } \\
\text { depending on } \\
\text { nozzle and } \\
\text { pressure }\end{array}$} & \multirow{3}{*}{$\begin{array}{l}\text { Depends on } \\
\text { biomaterial } \\
\text { used }\end{array}$} \\
\hline & Pneumatic & & & & & \\
\hline & Syringe/piston & & & & & \\
\hline \multirow[t]{5}{*}{ Plane-based } & DLP/SLA & Fast for large and complex 3D models & Few bioinks available & High (more than 10 & High & Bioinks used \\
\hline & & Very high accuracy & Waste of bioink due to its & million per $\mathrm{mL}$ )Ml) & & \\
\hline & & & conception & & & photocurable \\
\hline & & & & & & by DLP/SLA \\
\hline & & & & & & technology \\
\hline
\end{tabular}

Table 1. Most commonly used bioprinting technologies. 


\begin{tabular}{|c|c|c|c|c|c|c|c|c|c|}
\hline & Material & Type of bioink & $\begin{array}{l}\text { Bioprinting } \\
\text { technology }\end{array}$ & $\begin{array}{c}\text { Tissue } \\
\text { engineering model }\end{array}$ & Cancer models & Advantages & Drawbacks & $\begin{array}{c}\text { Type of } \\
\text { crosslinking }\end{array}$ & References \\
\hline \multirow{4}{*}{ 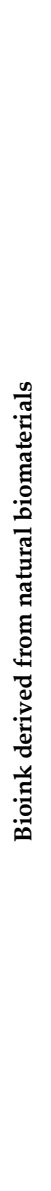 } & $\begin{array}{l}\text { Alginate- } \\
\text { based }\end{array}$ & $\begin{array}{l}\text { Natural } \\
\text { polysaccharide } \\
\text { (brown algae) }\end{array}$ & $\begin{array}{c}\text { Drop-based } \\
\text { Filament-based }\end{array}$ & $\begin{array}{l}\text { Vascular, cartilage, } \\
\text { bone, neural tissue, } \\
\text { fibroblasts, and } \\
\text { many more }\end{array}$ & $\begin{array}{l}\text { Drug delivery } \\
\text { Cancer stem cell } \\
\text { research } \\
\text { Breast cancer, } \\
\text { melanoma, and many } \\
\text { more } \\
\text { Tumor Spheroids }\end{array}$ & $\begin{array}{l}\text { Low cost } \\
\text { Good printability } \\
\text { Excellent bio-compatibility }\end{array}$ & $\begin{array}{l}\text { Poor cell adhesion } \\
\text { Fast degradation }\end{array}$ & Ionic & [18-24] \\
\hline & Gelatin-based & $\begin{array}{l}\text { Natural protein } \\
\text { (bovine skin and } \\
\text { tendon) }\end{array}$ & $\begin{array}{l}\text { Drop-based } \\
\text { Filament-based } \\
\text { Plane-based }\end{array}$ & $\begin{array}{l}\text { Vascular, cartilage, } \\
\text { bone, muscle, } \\
\text { fibroblasts, and } \\
\text { many more }\end{array}$ & $\begin{array}{l}\text { Cholangiocarcinoma, } \\
\text { bladder cancer, and } \\
\text { many more } \\
\text { Tumor spheroids }\end{array}$ & $\begin{array}{l}\text { Excellent bio-compatibility } \\
\text { Low-cost } \\
\text { High cellular adhesion }\end{array}$ & $\begin{array}{c}\text { Low viscosity at room or higher } \\
\text { temperatures } \\
\text { Need a temperature-controlled } \\
\text { (cooled printhead) and a cooled } \\
\text { printbed } \\
\text { Low mechanical strength (higher if } \\
\text { blended with methacrylate) }\end{array}$ & $\begin{array}{l}\text { Physical } \\
\text { Thermal } \\
\text { UV } \\
\text { Covalent } \\
\text { Enzymatic }\end{array}$ & {$[22,25-30]$} \\
\hline & $\begin{array}{c}\text { Cellulose and } \\
\text { nanocellulose } \\
\text {-based }\end{array}$ & $\begin{array}{c}\text { Natural } \\
\text { polysaccharide } \\
\text { obtained from the } \\
\text { biosynthesis of } \\
\text { plants or bacteria }\end{array}$ & Filament-based & Cartilage and bone & $\begin{array}{c}\text { Drug delivery } \\
\text { Gastric, cervical, } \\
\text { pancreatic cancer, and } \\
\text { many more }\end{array}$ & $\begin{array}{l}\text { Great similarity with ECM } \\
\text { Excellent bio-compatibility }\end{array}$ & $\begin{array}{l}\text { Low viscosity for cellulose } \\
\text { nanocrystals } \\
\text { Mainly used mixed with other natural } \\
\text { biomaterials }\end{array}$ & $\begin{array}{l}\text { Enzymatic } \\
\text { UV }\end{array}$ & [31-35] \\
\hline & Matrigel & $\begin{array}{l}\text { Solubilized } \\
\text { basement } \\
\text { membrane matrix } \\
\text { secreted by } \\
\text { Engelbreth-Holm- } \\
\text { Swarm (EHS) } \\
\text { mouse sarcoma } \\
\text { cells }\end{array}$ & $\begin{array}{l}\text { Filament-based } \\
\text { Drop-based }\end{array}$ & $\begin{array}{l}\text { Vascular, liver, } \\
\text { bone, lung, and } \\
\text { many more }\end{array}$ & $\begin{array}{l}\text { Tumor spheroids } \\
\text { Many types of cancer }\end{array}$ & $\begin{array}{l}\text { Most used material in } \\
\text { cancer research } \\
\text { Excellent bio-compatibility } \\
\text { Very well characterized for } \\
\text { organoid/spheroid } \\
\text { formation }\end{array}$ & $\begin{array}{l}\text { Cannot be used alone due to its } \\
\text { complex rheological behavior and } \\
\text { low mechanical properties } \\
\text { Limited use in vivo due to its mouse } \\
\text { tumor origin } \\
\text { Expensive } \\
\text { High batch variability }\end{array}$ & Thermal & [36-40] \\
\hline
\end{tabular}




\begin{tabular}{|c|c|c|c|c|c|c|c|c|}
\hline $\begin{array}{l}\text { Collagen-I- } \\
\text { based }\end{array}$ & $\begin{array}{l}\text { Natural protein (rat } \\
\text { tail or } \\
\text { bovine skin and } \\
\text { tendon) }\end{array}$ & $\begin{array}{c}\text { Drop-based } \\
\text { Filament-based }\end{array}$ & $\begin{array}{l}\text { Hard tissues (bone, } \\
\text { osteochondral, } \\
\text { cartilage) } \\
\text { Skin, } \\
\text { cardiovascular and } \\
\text { liver tissues, } \\
\text { nervous system, } \\
\text { and cornea }\end{array}$ & $\begin{array}{c}\text { Tumor spheroids } \\
\text { Neuroblastoma, breast } \\
\text { cancer }\end{array}$ & $\begin{array}{l}\text { Excellent bio-compatibility } \\
\text { High cellular adhesion } \\
\text { Minimal immunogenicity } \\
\text { Excellent printability } \\
\text { Enzymatically } \\
\text { degradability } \\
\text { Mechanical and structural } \\
\text { properties close to native } \\
\text { tissue } \\
\end{array}$ & Low shape fidelity & $\begin{array}{c}\mathrm{pH} \\
\text { Thermal }\end{array}$ & [41-44] \\
\hline $\begin{array}{l}\text { Hyaluronic- } \\
\text { acid-based }\end{array}$ & $\begin{array}{l}\text { Natural } \\
\text { polysaccharide } \\
\text { (bacterial } \\
\text { fermentation or } \\
\text { animal products) }\end{array}$ & Filament-based & $\begin{array}{l}\text { Hard tissues (bone, } \\
\text { osteochondral, } \\
\text { cartilage) }\end{array}$ & $\begin{array}{l}\text { Tumor spheroids } \\
\text { Melanoma, breast cancer }\end{array}$ & $\begin{array}{l}\text { Excellent bio-compatibility } \\
\text { Highly tunable (wide } \\
\text { variety and high degree } \\
\text { of potential chemical } \\
\text { modifications) } \\
\text { Interact with cell receptors }\end{array}$ & $\begin{array}{l}\text { Poor mechanical strength } \\
\text { Mainly used mixed with other natural } \\
\text { biomaterials }\end{array}$ & $\begin{array}{l}\text { Depends on } \\
\text { the other } \\
\text { biomaterial/ch } \\
\text { emical } \\
\text { modifications } \\
\text { Physical or } \\
\text { covalent }\end{array}$ & [45-48] \\
\hline $\begin{array}{l}\text { Agarose- } \\
\text { based }\end{array}$ & $\begin{array}{c}\text { Natural } \\
\text { polysaccharide } \\
\text { derived from red } \\
\text { seaweed }\end{array}$ & Filament-based & $\begin{array}{l}\text { Bone, Vvscular, } \\
\text { neural tissue, } \\
\text { adipose tissue }\end{array}$ & Leukemia & $\begin{array}{l}\text { Good biocompatibility } \\
\text { Great similarity with ECM } \\
\text { Thermo-reversible gelling }\end{array}$ & $\begin{array}{l}\text { Poor cell survival if not blended with } \\
\text { another biomaterial } \\
\text { Poor printability (needs high } \\
\text { temperature for dispensing }\left(70^{\circ} \mathrm{C}\right) \\
\text { and gels at low temperatures) } \\
\end{array}$ & $\begin{array}{l}\text { Thermal } \\
\text { Ionic }\end{array}$ & {$[37,49,50]$} \\
\hline Fibrin-based & $\begin{array}{l}\text { Natural protein } \\
\text { (human plasma) }\end{array}$ & $\begin{array}{l}\text { Filament-based } \\
\text { Drop-based }\end{array}$ & $\begin{array}{l}\text { Muscular, neural, } \\
\text { skin and adipose } \\
\text { tissue, wound } \\
\text { healing model }\end{array}$ & $\begin{array}{l}\text { Drug release } \\
\text { Glioblastoma }\end{array}$ & $\begin{array}{c}\text { High shape fidelity } \\
\text { (depending on fibrinogen- } \\
\text { thrombin concentration) } \\
\text { Excellent biocompatibility } \\
\text { Enzymatically degradable }\end{array}$ & $\begin{array}{l}\text { Medium cell adhesion } \\
\text { Low mechanical properties }\end{array}$ & $\begin{array}{c}\text { Enzymatic } \\
\text { (fibrinogen- } \\
\text { thrombin) }\end{array}$ & [51-53] \\
\hline Silk-derived & $\begin{array}{l}\text { Natural protein } \\
\text { (bombyx mory) }\end{array}$ & Filament-based & $\begin{array}{l}\text { Hard tissues (bone, } \\
\text { osteochondral, } \\
\text { cartilage), vascular } \\
\text { tissue }\end{array}$ & Drug delivery & $\begin{array}{l}\text { High shape fidelity } \\
\text { Low Cost } \\
\text { Good biocompatibility }\end{array}$ & $\begin{array}{c}\text { Lacks cell-binding domains } \\
\text { Medium cell viability } \\
\text { Needs other supportive material for } \\
\text { cell proliferation (alginate, gelatin, } \\
\text { etc.) } \\
\text { Poor printability performance }\end{array}$ & $\begin{array}{l}\text { Enzymatic } \\
\text { Physical }\end{array}$ & [54-57] \\
\hline Gellan gum & $\begin{array}{c}\text { Natural } \\
\text { polysaccharide }\end{array}$ & Filament-based & $\begin{array}{l}\text { Hard tissues (bone, } \\
\text { osteochondral, } \\
\text { cartilage), brain- } \\
\text { like structures }\end{array}$ & Drug delivery & $\begin{array}{c}\text { Excellent biocompatibility } \\
\text { Low cost } \\
\text { Rapid gelation }\end{array}$ & Poor printability performance & Thermal & [58-60] \\
\hline
\end{tabular}




\begin{tabular}{|c|c|c|c|c|c|c|c|c|}
\hline Chitosan & $\begin{array}{c}\text { Natural } \\
\text { polysaccharide } \\
\text { produced by } \\
\text { deacetylation of } \\
\text { chitin (extract from } \\
\text { shrimps) } \\
\end{array}$ & $\begin{array}{l}\text { Filament-based } \\
\text { Drop-based } \\
\text { Plane-based }\end{array}$ & $\begin{array}{l}\text { Hard tissues (bone, } \\
\text { osteochondral, } \\
\text { cartilage), vascular, } \\
\text { skin, hepatic } \\
\text { tissues }\end{array}$ & Drug delivery & $\begin{array}{l}\text { Good biocompatibility } \\
\text { Medium to high cell } \\
\text { viability }\end{array}$ & $\begin{array}{l}\text { Medium cell adhesion } \\
\text { Low shape fidelity } \\
\text { Low mechanical properties }\end{array}$ & $\begin{array}{l}\text { Ionic } \\
\text { UV }\end{array}$ & [61-63] \\
\hline Polypeptides & $\begin{array}{c}\text { Corning } \\
\text { (PuraMatrix) }\end{array}$ & $\begin{array}{c}\text { Filament-based } \\
\text { Droplet-based } \\
\text { Plane-based }\end{array}$ & Liver, neural & Ovarian cancer & $\begin{array}{c}\text { Self-assembly } \\
\text { Adapted for soft-tissue } \\
\text { applications and in } \\
\text { conjunction with other } \\
\text { materials } \\
\end{array}$ & Low pH leading to low cell viability & $\begin{array}{l}\text { Ionic- } \\
\text { complementar } \\
\text { y self- } \\
\text { assembly }\end{array}$ & {$[64,65]$} \\
\hline $\begin{array}{c}\text { De- } \\
\text { cellularized } \\
\text { matrix-based } \\
(\mathrm{dECM})\end{array}$ & Natural matrix & Filament-based & $\begin{array}{l}\text { Adipose, hepatic, } \\
\text { heart tissues, } \\
\text { MSCs, cancer } \\
\text { models }\end{array}$ & $\begin{array}{l}\text { Many tumor models } \\
\text { depending on dECM }\end{array}$ & $\begin{array}{l}\text { Renders natural ECM } \\
\text { Tissue-specific }\end{array}$ & $\begin{array}{l}\text { Low mechanical properties } \\
\text { Protein denaturation during } \\
\text { fabrication processes } \\
\text { Poor printability if not mixed with } \\
\text { another biomaterial } \\
\text { Long procedure } \\
\end{array}$ & $\begin{array}{l}\text { Depends on } \\
\text { the other } \\
\text { biomaterial/ch } \\
\text { emical } \\
\text { modifications }\end{array}$ & [66-69] \\
\hline $\begin{array}{c}\text { AM } \\
\text { (acrylamide) }\end{array}$ & Polyacrylamide & $\begin{array}{l}\text { Filament-based } \\
\text { Plane-based } \\
\text { Droplet-based }\end{array}$ & $\begin{array}{l}\text { Different stiffness } \\
\text { models }\end{array}$ & Melanoma, breast cancer & $\begin{array}{l}\text { Wide range of elasticity } \\
\text { Most standardized protocol }\end{array}$ & $\begin{array}{l}\text { Suitable for 2D culture only or } \\
\text { necessary to couple it with } \\
\text { another material }\end{array}$ & UV & {$[70,71]$} \\
\hline PCL/PLGA & $\begin{array}{l}\text { Poly(caprolactone)/ } \\
\text { Poly(lactic-glycolic } \\
\text { acid) }\end{array}$ & $\begin{array}{l}\text { Filament-based } \\
\text { Drop-based }\end{array}$ & $\begin{array}{l}\text { Hard tissues (bone, } \\
\text { osteochondral, } \\
\text { cartilage) }\end{array}$ & & $\begin{array}{l}\text { Good mechanical strength } \\
\text { Controllable rate of } \\
\text { degradation }\end{array}$ & $\begin{array}{l}\text { Mainly used as a scaffold (melting } \\
\text { temperature around } 60^{\circ} \mathrm{C} \text { not } \\
\text { compatible with cell viability) } \\
\text { Needs other supportive material for } \\
\text { cell proliferation (alginate, gelatin, } \\
\text { etc.) }\end{array}$ & $\begin{array}{c}\text { Depends on } \\
\text { the natural } \\
\text { biomaterial } \\
\text { used }\end{array}$ & {$[72-74]$} \\
\hline PEG & $\begin{array}{c}\text { Polymer of ethylene } \\
\text { oxide }\end{array}$ & Filament-based & $\begin{array}{l}\text { Vascular and bone } \\
\text { tissue }\end{array}$ & $\begin{array}{l}\text { Mainly depends on the } \\
\text { natural biomaterial used }\end{array}$ & $\begin{array}{l}\text { Highly tunable (mechanical } \\
\text { properties, polymerization, } \\
\text { chemical composition) }\end{array}$ & $\begin{array}{l}\text { Needs chemical modification to be } \\
\text { printed } \\
\text { Requires the addition of bioactive } \\
\text { molecules to allow cellular interaction } \\
\text { (high hydrophobicity) }\end{array}$ & $\begin{array}{l}\text { UV if mixed } \\
\text { with a } \\
\text { photoinitiator } \\
\text { Condensation } \\
\text { Michael-type } \\
\text { addition } \\
\text { Click } \\
\text { chemistry }\end{array}$ & [75-77] \\
\hline
\end{tabular}




\begin{tabular}{cccc}
\hline & $\begin{array}{c}\text { Triblock copolymer } \\
\text { of poly(ethylene } \\
\text { glycol)- } \\
\text { Pluronic } \\
\text { poly(propylene } \\
\text { oxide)- } \\
\text { poly(propylene } \\
\text { glycol) }\end{array}$ & Filament-based & Cartilage \\
& & & \\
& & & \\
PU & Polyurethane & Filament-based & $\begin{array}{c}\text { Cartilage } \\
\text { Neural stem cells }\end{array}$
\end{tabular}

\begin{tabular}{cccc}
\hline High shape fidelity & Lacks cell-binding domains & & \\
Good printability & $\begin{array}{c}\text { Low cell viability } \\
\text { Poor mechanical strength }\end{array}$ & Covalent & [78,79] \\
\hline $\begin{array}{c}\text { Good biocompatibility and } \\
\text { biodegradability } \\
\text { High mechanical strength }\end{array}$ & $\begin{array}{c}\text { Needs other supportive material for } \\
\text { cell proliferation (alginate, gelatin, } \\
\text { etc.) }\end{array}$ & $\begin{array}{c}\text { Depends on } \\
\text { the natural } \\
\text { biomaterial } \\
\text { used }\end{array}$ & [80,81] \\
\hline
\end{tabular}

Table 2. Examples of bioinks and their applications in cancer research. 


\section{Characterization of cells after bioprinting}

To evaluate the success of a bioprinting model, one of the most important parameters to assess is the viability and metabolic activity of the cells. Indeed, it is necessary to find the adequate printing parameters that allow obtaining the structural integrity of the hydrogel, that it is reproducible and especially viable. These parameters must be determined for each type of bioink and even for each concentration. Printing parameters such as the bed or cartridge temperature, pressure, and printing speed will modify the viscosity of the gel, which will affect the shear stress exerted on the cells and, therefore, their viability. This is also impacted by the way the hydrogels are crosslinked.

A plethora of techniques is available to characterize cells after bioprinting to determine the size and organization of the constructs, cell viability, and metabolism, and the level of gene and protein expression [82,83] (Table 3 and 4, Figure 3). The size and shape of the constructs must be adapted to the technique used. For example, microscopic analysis does not require many cells, in contrast to cytometry, molecular biology technics, or spectrometric analysis. After adaptation, the usual techniques used in conventional 2D culture can be applied.

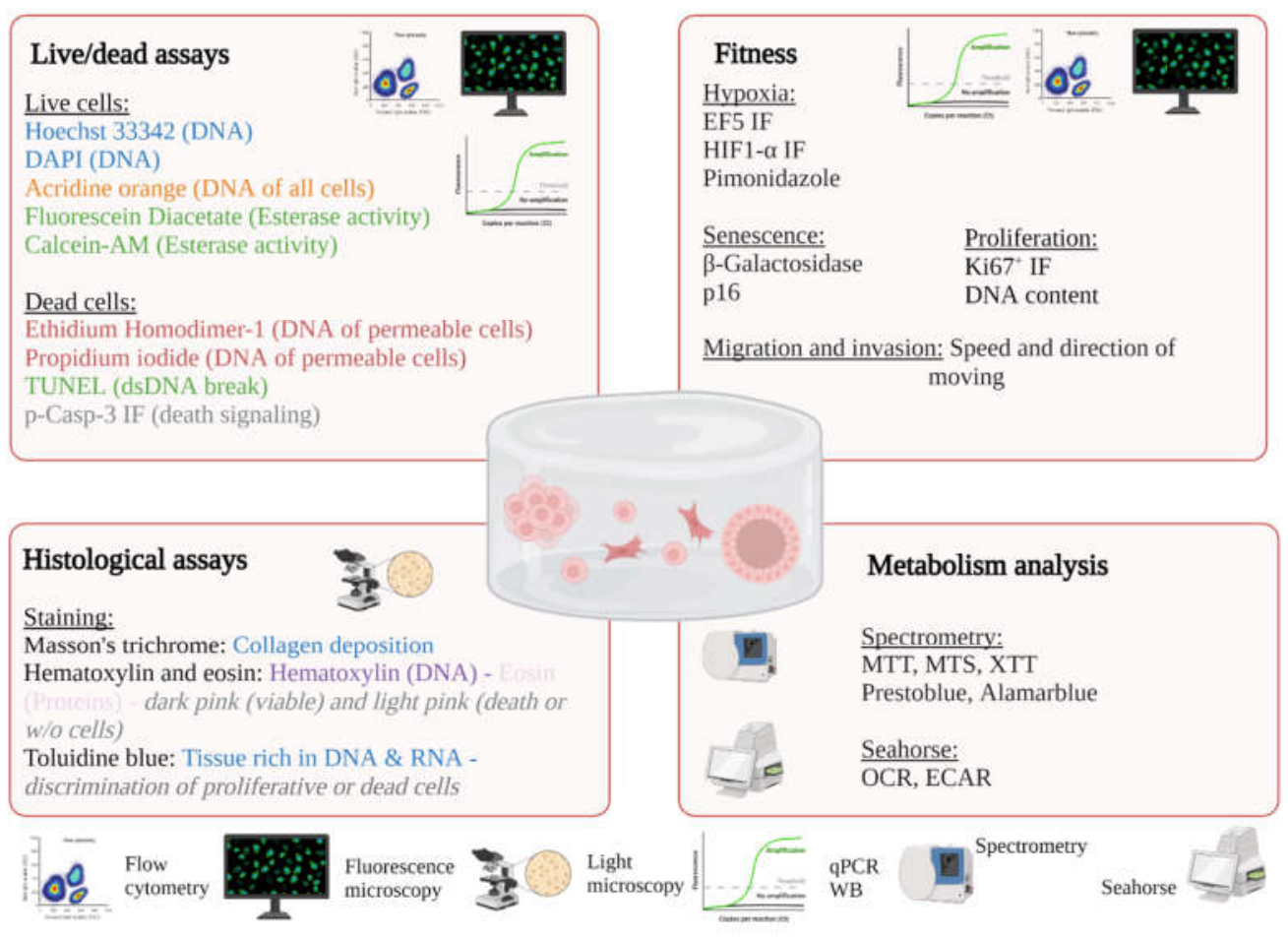

Figure 3. Examples of possible analysis of 3D bioprinted constructs.

\section{a. In situ characterization of cells}

The advantage of using techniques where the cells are embedded in the hydrogel allows avoiding artifacts related to the dissociation of the hydrogel.

\section{i. Light microscopy}

Microscopy is particularly interesting in the characterization of hydrogels because it allows the structure of the construct to be preserved as well as the cell-cell interactions. It allows access to the size and morphology of cells that could assemble into spheroids or in 
a native tissue organization. Phase-contrast microscopy allows monitoring cell proliferation and growth over time without inducing toxicity [84-86]. However, because the cells are alive, the acquisition time should not be too long to avoid inducing cell death. This technique is only possible for optically transparent hydrogels. For example, the cell-ink bioink composed of alginate and cellulose nanofibril is opaque and does not track cells without prior fluorescent labeling or end-point histological analysis.

Histological analysis requires sample preparation, including fixing, cutting, and staining [85-87]. The preparation steps for sectioning are very important. Dehydration for paraffin embedding tends to shrink the size of the sample and is therefore not be recommended for structural or organizational measurements [88]. In addition, if the hydrogel pores are not completely filled with paraffin, this will promote folding during sectioning and detachment of the sample from the section. However, the advantage of this technique is the possibility of having thin sections (up to $5 \mu \mathrm{m}$ thick). In contrast, cryosection preserves the hydrogel structure, particularly with polyvinyl alcohol (PVA) and optimum cutting temperature $(\mathrm{OCT} \cap)$ preparation. However, the sections are thicker, and more aspecific markings can be observed with a protein-based cryoprotectant solution [89]. Using resins favors the preservation of structures but makes it more difficult to perform histological stains [90]. Finally, it is possible to proceed directly to histological staining without cutting to visualize the cells on the surface of the hydrogel. Depending on the structures of interest, different stainings are available: Masson's trichrome (TM) stains collagenous structures in blue (fibrosis, for example); hematoxylin (DNA) and eosin (proteins) illuminates viable zones in dark pink and dead zones in clear pink; and finally, toluidine blue highlights the zones rich in RNA and DNA. Trypan blue is used to stain dead cells [91]. Quantification of chromatic staining can be difficult on thick samples, so the use of fluorescence microscopy is a good alternative.

\section{ii. Fluorescence microscopy}

Fluorescence microscopy is used to label subcellular structures such as the cytoskeleton (F-actin), mitochondria (mitoTracker), nuclei (Hoechst), or other types of organelles or proteins [92-95]. Standard immunofluorescence or biomarker labeling protocols can be applied to the hydrogel, although the times of the different labeling steps should be increased or even improved using mechanical agitation or vacuum. Observation of the organization and viability of cells as a function of the position or shape of the hydrogel is only possible under microscopy. Using markers or antibodies coupled to fluorescent probes, it is possible to determine whether cells are dying (p-casp3), proliferating (KI67+ or DNA), entering in senescence (p16 or $\beta$-galactosidase), or in a hypoxic environment (HIF1- $\alpha$, EF5, pimonidazole). Numerous fluorescence assays for dead/live cells are described in Table 2; however, the most commonly used combination of fluorochromes are calcein-AM stain for esterase activity (live cells) and propidium iodide for permeable and therefore dead cells. It is possible to combine one of these two markers with Hoechst3342 or DAPI; however, this is not possible in all types of hydrogels, such as alginate, which shows strong auto-fluorescence from the UV channel. An easy-to-use marker for studying cell morphology is phalloidin labeling of F-actin, which is particularly interesting in models for studying mechanotransduction as a function of support stiffness, for example [91,96-98].

For high-resolution microscopy, confocal imaging is the reference method for studying cells embedded in the hydrogel. The disadvantage is the necessity to print thin film constructs on suitable substrates. Indeed, without a clearing technique, only $100 \mu \mathrm{m}$-thick constructs can be imaged. Furthermore, these hydrogels should preferably be printed on glass coverslips to favor high-resolution imaging. The risk is that the hydrogel may become detached; to mitigate this, the silanization of the coverslips allows the covalent bonding of the gel with its support. To limit the constraints of confocal imaging, other microscopy techniques have been developed, such as light sheet imaging. It is thus possible to image large objects without a physical section with limited phototoxicity [92-95].

\section{iii. Electronic microscopy}


Electron microscopy provides nanoscale imaging, either scanning for the sample's surface or transmission for the internal structures [86,99]. These techniques allow the study of cell-cell or cell-ECM interactions, but also cell death. However, the sample preparation steps can change the structure of the sample.

iv. Colorimetric and fluorimetric methods

It is also possible to access the viability, proliferation, and metabolism of cells contained in hydrogels without dissociating them via colorimetric or fluorimetric methods. For this purpose, the use of prestoblue or alamar blue is an interesting solution because it is non-toxic for the cells, and it is possible to follow viability and proliferation over time. This test is based on reducing resurin to form resofurin, a red fluorescent compound. The test can be revealed by fluorimetry or absorbance reading [100-102]. Many tests exist to measure mitochondrial activity in cells, such as MTT, MTS, XTT, WTS, and CCK8, but MTT, for example, requires the dissolution of formazan crystals [96,103-105]. These tests are toxic to the cells and should be performed as an endpoint. All these techniques can be coupled with the measurement of lactate dehydrogenase release in the cell supernatant, revealing the membrane permeability of the cells [103]. Furthermore, background noise can be detected, so it is always necessary to make hydrogels without cells to manage this parameter. Generally, the same protocol as for the cells can be used; however, the incubation times may, in some cases, be slightly longer. Kits have been developed and adapted for 3D hydrogels, such as Celltiter-Glo 3D, which favors the penetration of reagents and has a better lytic capacity[85,100,106].

v. Metabolic fluxes analysis

Cancer cell metabolism greatly influences tumor growth and resistance to anti-cancer treatments[107,108]. The organization of cancer cells into hydrogel allows mimicking the heterogeneity that can be found in tumors in vivo as the difference in access to nutrients and oxygen and highlights the need to develop techniques to analyze the metabolism of cells in the hydrogel. Metabolic fluxes provide a detailed metric of the cellular metabolic state. For example, it is possible to place fluorodeoxyglucose ([18F]-FDG tracer) in the culture medium and monitor its localization and consumption in the hydrogel. This technique is particularly interesting as it can be performed in animals in the pre-clinical study phase; however, the resolution is rather limited $(1.5 \mathrm{~mm}$ on average) $[104,109]$. Glycolysis and mitochondrial respiration can be assessed by the Seahorse XF flux analyzer via the extracellular acidification rate (ECAR) or the oxygen consumption rate (OCR) [110-112]. However, this measure is global and does not consider heterogeneity in the sample. Furthermore, it is necessary to print small constructs with a large number of cells and sometimes to extend the measurement time.

The flux of extracellular metabolites can be determined by taking a small volume of the culture medium in contact with the spheroids at regular intervals, for example, every 4 hours $[113,114]$. The measurement of glucose and lactate, as well as glutamine and glutamate, can be measured using a clinical biochemistry analyzer or different kits. Extracellular fluxes were determined from the slopes of the fitted functions (mol/h/L) and by normalizing these results by the number of cells and the volume of the well. Finally, the intracellular metabolic flux can be determined using isotopes using NMR (nuclear magnetic resonance) $[114,115]$ or GC-MS (gas chromatography-mass spectrometry) $[113,116]$ and materials other than NMR (0.5mg dry mass) [116]. From the cytoplasmic extracts, it is possible to determine the active amino acid synthesis pathways.

\section{b. Characterization of cells after isolation or lysis}

\section{i. Molecular Biology}

For many applications in tissue engineering, it is necessary to be able to extract, DNA, mRNA or protein in order to monitor different cellular parameters such as differentiation or certain functions. It is also possible to determine proliferation and viability via the measurement of DNA concentration. This technique is interesting since it allows to know the number of cells per gel, but also to normalize the data obtained to the number of cells. 
However, it is critical to find the right technique to lyse the cells to recover the full amount of DNA. For example, for alginate gels, it is possible to use a commercial solution, the purelink genomic DNA mini kit [117]. For GelMa or agarose, the use of EDTA associated with proteases allows the recovery of cells from the gel in order to assay the DNA [97,98,118-121].

Conventional methods for 2D cell culture rely on two methods, either via the use of phenol/chloroform or with commercial kits using silica membranes in spin columns [122]. However, the inclusion of cells in hydrogels makes this step more difficult and it presents more challenges that are technical. Indeed, the classical RNA extractions often does not allow obtaining RNAs in sufficient quantity and/or quality for the subsequent performance of RTqPCR. Köster's team conducted a study to investigate homogenization methods and RNA extraction techniques based on the most commonly used hydrogels (alginate, gelatin and agarose) on hMSC cells[123]. For this purpose, 4 homogenization techniques are deployed. Regardless of the type of hydrogel, homogenization techniques using liquid nitrogen or a rotor stator should be excluded as the yield of RNA is very low. In contrast, the amount of RNA is much higher for techniques using the micro-homogenizer or enzymatic/chemical digestion. The technique of Frozen liquid nitrogen, crushed by electric crusher seems to be relevant for GelMa-type homogenization [97,118][97,118]. For extraction, Köster's . For extraction, Köster's team shows that conventional commercial kits using silica membranes in spin columns do not provide a correct RNA yield for hMSC in alginate, gelatin and agarose hydrogel [123]. However, other teams obtain satisfactory results with agarose-based or alginate hydrogels [98,124]. Hot phenol (HP), Trizol (TR), cetyltrimethylammonium bromide (CTAB), $\mathrm{LiCl}(\mathrm{LC})$ techniques have a better RNA yield, but the LiCL technic gives poor PCR results (example dominating additional band, PCR product with incorrect size or no PCR product). For the same reasons, the trizol technique is not adapted for alginate gels for Köster's team but it's for Ewa-Choy's or Sbrana's Teams $[102,117]$. Hot phenol and CTAB seem to be the most suitable technics; hot phenol gives the best RNA yield, CTAB the best RNA quality (equivalent to 2D culture) and low endpoint $\mathrm{Ct}$ values $\sim 20$.

\section{ii. Flow cytometry}

It can also be interesting to isolate cells to either promote cell expansion or analysis using flow cytometry, as this allows many cells to be analyzed very quickly. For this purpose, enzymatic degradation is possible for matrices derived from natural products such as collagenase for GelMA or collagen hydrogels, hyaluronidase for hyaluronic acid-based gels, or alginate lyase for alginate hydrogels. Some materials can also be degraded by physical techniques such as photo-degradation [125]. This step is critical because a tooprolonged enzyme treatment can induce significant cell death or even alter the membrane receptors. The limitation of this technique also lies in the fact that a large hydrogel is required to recover the necessary number of cells after degradation [126]. Then, standard labeling protocols such as 2D culture can be used. Flow cytometry allows quantitative measurements of many parameters simultaneously, such as viability, proliferation, cell cycle, and uptake of anti-cancer agents. As for microscopy, live/dead tests based on calcein-AM and ethidium are the most commonly used, with propidium iodide or brdu for the cell cycle. It is also interesting to use this technique to identify subpopulations or maintenance of a phenotype such as chronic lymphocytic leukemia cells on $\mathrm{CD}^{+} \mathrm{CD}^{+}{ }^{+} \mathrm{IgM}^{+}$markers [102]. The disadvantage of flow cytometry compared to microscopy is the loss of spatial information. To compensate for this, Beaumont's team developed a protocol based on the diffusion gradient of Hoechst 33342, which makes it possible to discriminate between internal and peripheral cells according to the intensity of Hoechst [127]. 


\begin{tabular}{|c|c|c|c|c|c|}
\hline & Description & Pros and cons & Markers & REF \\
\hline \\
\hline \multirow[t]{2}{*}{ Light } & Phase contrast & $\begin{array}{l}\text { Monitoring of proliferation and } \\
\text { morphology of cells }\end{array}$ & $\begin{aligned} &+ \text { ・ Nondestructive } \\
& \bullet \text { No markers are added } \\
& \text { - Low cost } \\
& \text { - Easy with transparent gels (GelmA, matrigel) } \\
&-: \text { - No possibility to identify subcellular structures } \\
& \text { - Difficult with opaque or non-transparent gels } \\
& \text { (e.g: alginate with nanocellulose) }\end{aligned}$ & Not suitable & [84-86] \\
\hline & Bright field & $\begin{array}{l}\text { The transmission of light is more or less } \\
\text { attenuated depending on the density or } \\
\text { marking of the sample }\end{array}$ & $\begin{aligned} &+ \text { - Suitable for large samples } \\
&-: \text { - Requires histological staining } \\
& \text { - Preparation of sample } \\
& \text { - Quantification of thick sample } \\
&\end{aligned}$ & $\begin{array}{l}\text { Hematoxylin-eosin } \\
\text { Masson's trichrome } \\
\text { Trypan blue }\end{array}$ & [85-87] \\
\hline \multirow[t]{4}{*}{ Fluorescence } & LSM & \multirow{4}{*}{$\begin{array}{l}\text { The use of a fluorescent marker is } \\
\text { necessary to highlight a subcellular } \\
\text { structure. Possibility of monitoring } \\
\text { structures over time (if vital markers) }\end{array}$} & \multirow{4}{*}{$\begin{array}{l}+: \text { - Monitoring of many possible structures } \\
-: \text { - Requires cutting for oversized constructions } \\
\text { for epi and confocal microscopy } \\
\text { • Need to fix for certain markers } \\
\text { •Important autofluorescence for chitosan or } \\
\text { alginate/cellulose hydrogels in UV }\end{array}$} & Live/dead staining & \\
\hline & Epifluorescence & & & Calceine- & $95,128]$ \\
\hline & Confocal & & & $\begin{array}{l}\text { AM/Propidium iodide } \\
\text { Or Ethidium homodimer }\end{array}$ & \\
\hline & & & & $\begin{array}{l}\text { Active-caspase } 3 / 7 \text { green } \\
\text { Hoechst } 33342 \\
\text { HIF1- } \alpha, \text { Ki } 67\end{array}$ & \\
\hline \multirow[t]{2}{*}{ Electronic } & Scanning & $\begin{array}{l}\text { Surface is scanned with a beam of } \\
\text { electrons, emitted signal provides } \\
\text { images }\end{array}$ & \multirow[t]{2}{*}{$\begin{array}{l}+: \bullet \text { High resolution } \\
-: \bullet \text { The preparation procedure is tedious } \\
\quad \bullet \text { Frequent preparation artifacts (collapse) }\end{array}$} & Not suitable & {$[86]$} \\
\hline & Transmission & $\begin{array}{l}\text { The part of beam of electrons is } \\
\text { transmitted into specimens allowed to } \\
\text { obtain images }\end{array}$ & & Not suitable & {$[86,99]$} \\
\hline \multicolumn{6}{|l|}{ Flow cytometry } \\
\hline \multicolumn{2}{|c|}{ Flow cytometry } & $\begin{array}{l}\text { Analysis of physical parameters (size } \\
\text { and granularity) for each cell but also } \\
\text { the level of fluorescence }\end{array}$ & $\begin{array}{l}+: \text { Quantitative analysis } \\
-: \bullet \text { Disaggregation can be a problem } \\
\text { - Necessity to have a large cell number due to loss } \\
\text { of cells during dissociation }\end{array}$ & $\begin{array}{l}\text { 7-AAD } \\
\text { CFSE }\end{array}$ & {$[86,123]$} \\
\hline \multicolumn{6}{|l|}{ Spectroscopy } \\
\hline \multicolumn{2}{|c|}{ Spectrometry or fluorimetry } & $\begin{array}{l}\text { Production or utilization of a } \\
\text { fluorescent or chromatic compound }\end{array}$ & $\begin{array}{l}+: \text { Well-described for 2D culture and frequently } \\
\text { used } \\
\quad \text { - Can be used for kinetic monitoring }\end{array}$ & $\begin{array}{l}\text { ACP, } \quad \text { LDH, } \\
\text { prestoblue, alamar } \\
\text { blue, DNA content }\end{array}$ & $\begin{array}{l}{[96,103} \\
-105]\end{array}$ \\
\hline
\end{tabular}


- : • Ensure that the efficiency is adapted for 3D

\begin{tabular}{|c|c|c|c|c|}
\hline Molecular biology & & & & \\
\hline RTqPCR & \multirow{2}{*}{$\begin{array}{l}\text { Quantification of gene expression at } \\
\text { mRNA or protein level }\end{array}$} & \multirow[b]{2}{*}{$\begin{array}{l}+: \bullet \text { Quantitative analysis } \\
\text { - Easier by using the enzymatic method on natural } \\
\text { inks (e.g., collagenase for GelMa or ColMa, } \\
\text { hyaluronidase for hyaluronic acid) } \\
-\quad \text { : } \text { Adaptation of the homogenization and } \\
\text { extraction protocol to obtain an adequate quantity } \\
\text { and quality of RNA/proteins for analyses }\end{array}$} & \multirow{2}{*}{$\begin{array}{l}\text { Bax/Bcl2 } \\
\text { HIF1- } \alpha, \text { Ki67 }\end{array}$} & \multirow{2}{*}{$\begin{array}{l}{[87,99,1} \\
02]\end{array}$} \\
\hline Western blot & & & & \\
\hline \multicolumn{5}{|l|}{ Metabolism } \\
\hline $\begin{array}{l}\text { GC-MS (Gas chromatography-mass } \\
\text { spectrometry) }\end{array}$ & $\begin{array}{l}\text { Detection of molecules of interest } \\
\text { according to their mass/charge ratio } \\
\text { after ionization }\end{array}$ & $\begin{array}{l}+: \bullet \text { Considerably less cellular material compared to } \\
\text { NMR, high sensitivity, } \\
-: \bullet \text { Use of radioisotopes, complex sample } \\
\text { preparation, high cost }\end{array}$ & ${ }^{13} \mathrm{C}$-Glucose & $\begin{array}{l}{[113,11} \\
6]\end{array}$ \\
\hline $\begin{array}{l}\text { NMR (nuclear magnetic resonance) } \\
\text { spectroscopy }\end{array}$ & $\begin{array}{l}\text { Determination of the composition of a } \\
\text { sample by applying a magnetic field via } \\
\text { the orientation of the nuclear spins of } \\
\text { the atoms }\end{array}$ & $\begin{array}{l}+: \bullet \text { High reproducibility, sample can be analyzed } \\
\text { directly, low cost } \\
-: \bullet \text { Use of radioisotopes, low sensitivity }\end{array}$ & & $\begin{array}{l}{[114,11} \\
5]\end{array}$ \\
\hline $\begin{array}{lrl}\text { PET scan } & \text { (positron } & \text { emission } \\
\text { tomography) } & & \end{array}$ & $\begin{array}{l}\text { Injection of a radiographic tracer and } \\
\text { monitoring by imaging to detect } \\
\text { localization of }\left[{ }^{18} \mathrm{~F}\right] \mathrm{FDG}\end{array}$ & $\begin{array}{l}+: \bullet \text { Classically used in medicine, monitoring over } \\
\text { time } \\
-: \bullet \text { Low resolution }(1.5 \mathrm{~mm})\end{array}$ & {$\left[{ }^{18} \mathrm{~F}\right] \mathrm{FDG}$} & $\begin{array}{l}{[104,10} \\
9]\end{array}$ \\
\hline Seahorse & $\begin{array}{l}\text { Quantification of the oxygen } \\
\text { consumption rate (OCR) and the } \\
\text { extracellular acidification rate (ECAR) }\end{array}$ & $\begin{array}{l}+: \bullet \text { High sensitivity (from 5,000 cells, theoretically), } \\
\text { possibility to test many conditions in parallel } \\
-: \bullet \text { Difficulties to normalize results, limited number } \\
\text { of injections, limited sample thickness }\end{array}$ & Not suitable & $\begin{array}{l}{[110,11} \\
2]\end{array}$ \\
\hline
\end{tabular}

Table 3: Characterization technology of bioprinted constructs. 


\section{Value of 3D bioprinting for cancer modeling}

Actual models for cancer study range from in vitro traditional 2D cultures to in vivo models; most of the time, the complexity of the model goes hand in hand with the complexity of assaying the subsequent metabolism [129]. Three-dimensional bioprinting allows adding high-complexity tissue modeling in a relatively user-friendly technology (Figure 4). Compared to the widely used organoid approach, 3D bioprinting allows, in an automated way, the creation of complex 3D structures with precise and reproducible deposition of cells and matrices.

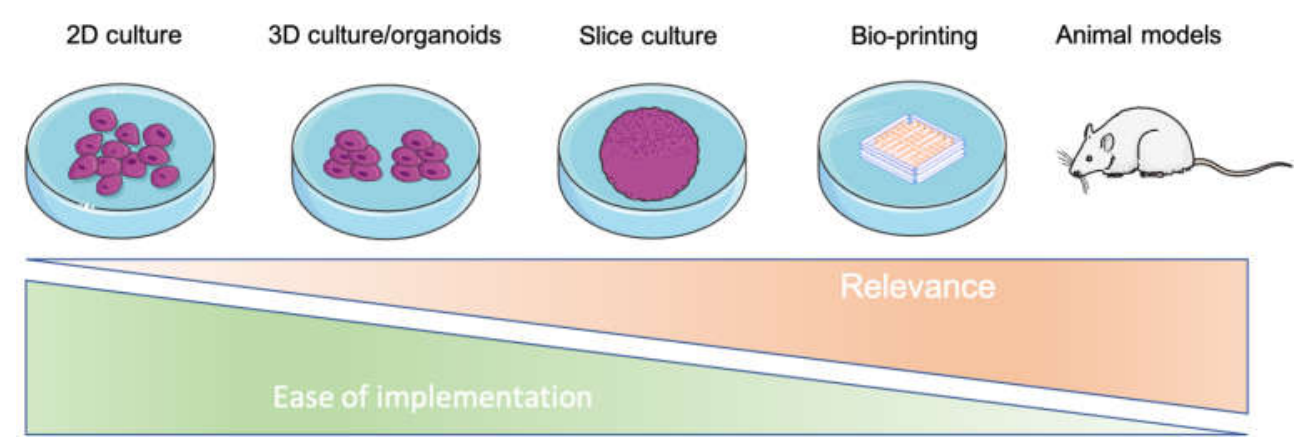

Figure 4: Relevance and ease of implementation of different research models.

Bioprinting is, therefore, an innovative approach to mimic the in vivo microenvironment of cancer cells as closely as possible (Figure 5). This has the advantage of producing more viable results that are closer to in vivo results, such as cell-cell or cell-ECM or resistance to treatment as a function of the microenvironment. One could also imagine mimicking the tumor microenvironment for each patient (personalized medicine) or for a cohort (biobanks) to test their responses and resistance to the different therapeutic lines. New bioprinting methods have also made it possible to obtain a greater number of cancer stem cells, cells that are particularly difficult to maintain in vitro and incriminated in cancer relapse. 


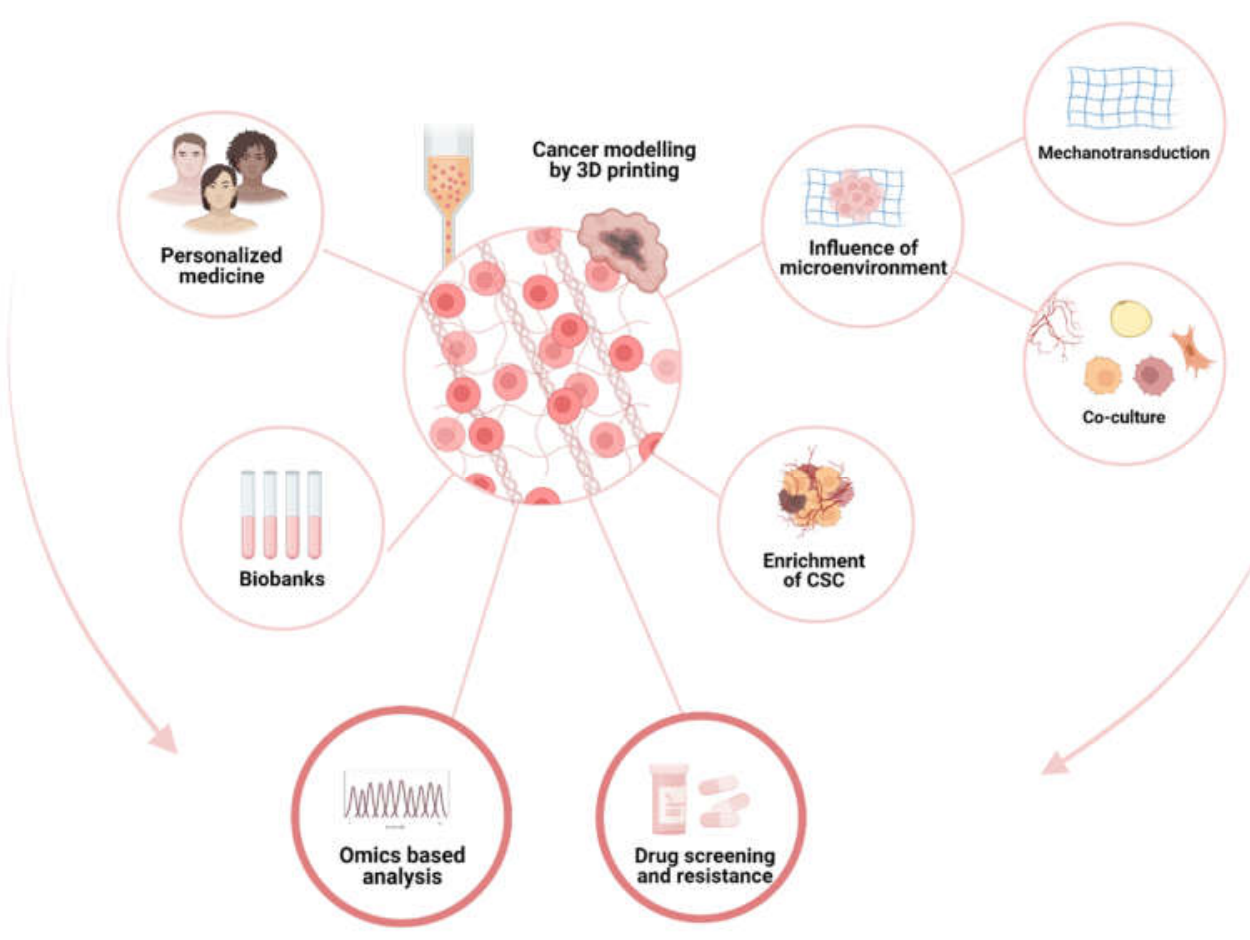

Figure 5: The value of bioprinting for oncology research.

\section{a. Recapitulate cancer's relation to the microenvironment}

\section{i. Cells-ECM interaction}

For a long time, the study of cancers was solely based on the precise genetic, metabolic, and phenotypic analysis of single tumor cells, with tumor stroma being totally ignored [130]. Recently, there has been strong evidence of stroma-tumor interactions related to tumor progression [131]. This cancer stroma is a complex framework of supportive tissue composed of the extracellular matrix (ECM), cells (such as fibroblasts and adipocytes), inflammatory and immune cells, and a specific vascularization. Thus, there are complex interactions between the stroma and the cancer cells: cancer cells can modify their stroma, and stroma can support tumor progression.

Adipocytes are a main component of the human body and are thus in the vicinity when tumorigenic events take place [132]. Complex crosstalk is then set up, in which phenotypical and functional modifications of both tumor cells and adipocytes occur. Adipocytes release fatty acids that can be oxidized in cancer cell mitochondria and thus provide energy through ATP in times of metabolic need [107]. In breast cancer, aberrant adipocytes called cancer-associated adipocytes (CAA) are known to promote invasion and metastasis of breast cancer, in particular through the secretion of adipocytokines in the invasive front of the tumor [133]. Horder et al. bioprinted a breast cancer model with adiposederived stromal cells (ADSC) [48]. ADSCs were differentiated into adipocytes within the hyaluronic acid gel and allowed the remodeling of the ECM with increased collagens I and IV and fibronectin expression, demonstrating the important interactions between cancer cells and adipose tissue.

Cancer-associated fibroblasts are another key component of the tumor microenvironment, notably through their capacity to remodel the extracellular matrix but also through direct cellular interactions via paracrine signals (exosomes, metabolites, and cytokines) with cancer and immune cells $[134,135]$. In a recent paper, Hanley et al. showed that targeting CAF could be a potential target to overcome resistance to anto-PD1/PD-L1 and CTLA-4 immunotherapy [136]. Mondal et al. printed non-small cell lung cancer (NSCLC) 
patient-derived xenograft (PDX) cells and lung CAFs that allowed high viability and efficient crosstalk [137].

Spheroids have long been used to complexify tumor models, but despite their 3D structure, they are not sufficient to recapitulate the complexity of the microenvironment, notably due to the lack of multiple cell types and vascularization. Three-dimensional bioprinting allows recapitulating the complexity of the tumor microenvironment, particularly through the precise deposition of several cell types, the ability to vary the type of matrix, and the ability to precisely set up vascularisation networks [138,139]. As reported by Samadian et al., ECM components and cells have a crucial role in the progression and spread of cancers, and 3D bioprinting allows mimicking the tumor microenvironment at physical, cellular, and molecular degrees [140]. The possibility of making sacrificial templates using sacrificial materials (e.g., pluronics F-127) allows the setting up of vessel-like structures that can be cellularized and perfused, improving nutrient availability [141]. Different strategies can be used for the printing of a vascular network that is recapitulated by Richards et al., but extrusion-based bioprinting is quite capable of printing complex networks (for review, see [142]).

\section{ii. Neoangiogenesis}

Angiogenesis is a normal mechanism by which new blood vessels can be generated. Angiogenesis is made up of different stages, including the degradation of the matrix via proteases and the migration and proliferation of endothelial cells to form new tubes that are anastomosed with pre-existing ones [143]. In a normal state, angiogenesis is mainly regulated by hypoxia, in particular through the hypoxia-inducible transcription factor (HIF) family [144]. To allow tumor growth, cancer cells will stimulate endothelial cells activity by releasing many soluble factors such as EGF, FGF, and VEGF. Tumor-endothelial interactions are also essential in metastasis processes.

Three-dimensional bioprinting allows studying the mechanisms at the origin of neoangiogenesis. As reported by Zervantonakis et al., 3D breast adenocarcinoma bioprinted models associated with microfluidics can recapitulate changes in the endothelial barrier caused by tumor-endothelial cells interactions and model the process of intravasation [145]. In a model of lung carcinoma, 3D bioprinting of a vascularized tissue allowed exploring the molecular mechanisms of metastasis by using a gradient of angiogenic factors such as EGF and VEGF in printed programmable release capsules [146].

iii. Migration and invasion

Metastases are secondary cancers that originate from the migration and invasion of cells from primary cancer, and their occurrence is the main cause of cancer-related deaths $(\sim 90 \%)$ [147]. Understanding the mechanisms involved in the genesis of metastasis remains a major challenge in the fight against cancer. Currently, the 3D method classically used is the Boyden chamber, where cells will migrate through a physical barrier containing pores (migration) or combined with a protein coating, often the matrigel, mimicking the ECM (invasion) [148]. However, this technique is often performed as an endpoint and does not allow screening with many conditions. Moreover, the matrigel is not very reproducible from one batch to another in terms of composition and stiffness.

In this sense, the team of Jung et al. developed a bioprinting platform to study the migration or invasion, i.e., the migration through the extracellular matrix of tumor cells with a drop-on-demand inkjet 3D bioprinter [149]. This technique allows analyzing the simultaneous migration of 96 conditions in parallel with very reproducible results, in hydrogels of varying stiffness, for example.

iv. Enrichment in cancer stem cells

A tumor comprises many differentiated cancer cells and a few cancer stem cells $(<0.001 \%$ of tumor cells). Relapse of some types of cancer may occur due to the presence of cancer stem cells (CSCs) that are resistant to various anti-cancer therapies (chemo-, targeted, or radiotherapy) or low $\mathrm{pH}$, oxygen, or glucose content [150] (Figure 6). These cells have the capacity for self-renewal, low cycling, and the ability to differentiate. The CSCs 
are particularly difficult to study in vitro as they are very poorly represented and do not have a single stemness-specific marker but a combination that does not strictly define this population. However, they have a phenotype that can drift under conventional culture conditions. Until now, the majority of methods used to isolate this CSC population were based on low adherence and low oxygen culture conditions as well as stimulation by chemotherapy [151-153]. Unfortunately, these techniques were time-consuming and did not always allow for the recovery of many cells. Recently, three-dimensional culture systems have been developed to enable conventional two-dimensional monolayers to mimic the in vivo microenvironment as closely as possible [152].

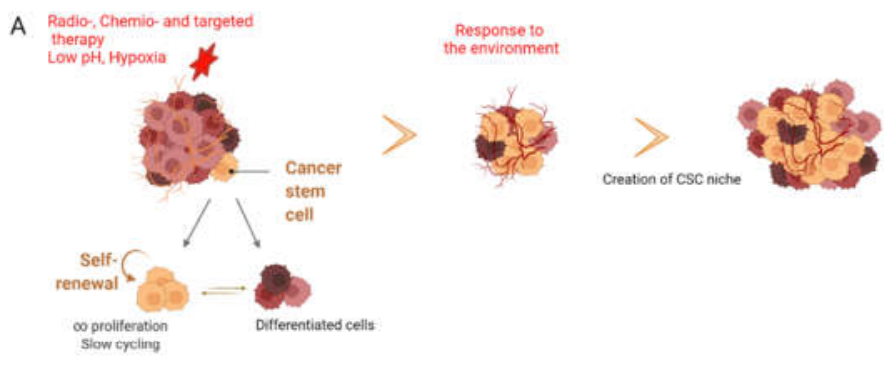

B
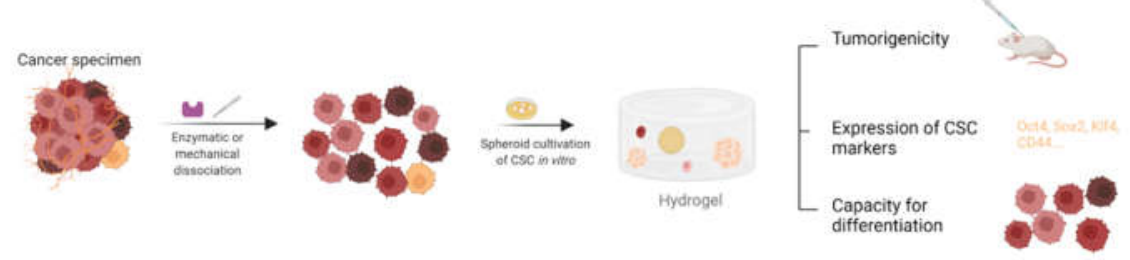

Figure 6: Cancer stem cell (CSC) and microenvironment. (A) A tumor is composed of heterogeneous cells, including a small fraction of cancer stem cells (in yellow). These cells are distinguished by their low cycling and their ability to self-renew and differentiate. When the tumor is exposed to treatments or a hypoxic or low nutrient environment, these cells will resist and survive in a niche that is adapted to them. (B) A large number of CSCs is of interest to test an effective personalized treatment for each patient. For this purpose, a tumor sample must be dissociated by enzymatic and/or mechanical treatment and then cultured in a 3D environment to promote the formation of spheroids in the hydrogel. These cells then show the capacity of tumorigenicity (tumor formation in vivo), overexpression of stemness markers such as Oct4 and Sox2, and finally, the capacity to differentiate.

The use of bioprinted cells in hydrogels may overcome these limitations, and the ability to mimic the native elastic environment of the cells may help to maintain stemness. The Suzuka team demonstrated that the seeding of cells on double PEG hydrogel network allowed rapid reprogramming of human differentiated tumor cells into CSCs within 24 hours of culture, for 6 human cancer cell lines (affecting brain, lung, uterine cervix, colon bladder, and synovium organ) or with brain cancer cells resected from patients with glioblastoma [154]. In all these conditions, upregulation of cancer stem cell marker genes is observed (Oct3/4, Nanog and Sox 2). Similarly, including cancer cells in alginate beads, in alginate/chitosan, chitosan/hyaluronic acid, or collagen hydrogel, increases the proportion of CSC with an upregulation of stemness genes for glioblastoma, breast, hepatocellular, and prostate cancer [155-161]. Similar results can be obtained with fibrous materials made of PCL[162].

\section{v. Mechanical environment \\ 1. Mechanotransduction}

It has now been well known for many years that cellular metabolism cannot be reduced to the functioning of an isolated cell. Cells grow and interact with their environment, notably via chemical and physical factors that can drive their fate. This mechanism 
of sensing, integrating, and responding to external signals is widespread in almost all living organisms. Chemical interactions mediated by soluble factors or cell-cell interactions have been extensively studied in the past; however, cell interactions with their environment and notably with the extracellular matrix (ECM) cannot be reduced to chemical stimuli. In recent years, physical cues have proved to be major regulators of the cell response to external stimuli, including the ability to sense external applied forces, rigidity, topography, and orientation [163-165]. The mechanism by which these external physical stimuli are detected, transmitted to the cell, and converted into biochemical information is called mechanotransduction [166]. The detection of external stimuli, also called mechanosensing, depends on the nature of the signal and is particularly mediated through focal adhesion complexes (FAs) (composed of multiple mechanosensors such as talin and vinculin), adherens junctions, and mechanically activated channels (e.g., Piezo) (for review, [167]). The microenvironment can induce different physical and mechanical stresses on tumor cells. The cell can be subjected to three different types of mechanical stress: (i) tensile stress, related to the contraction of actomyosin during the stiffening of the ECM; (ii) compressive stress, due to anarchic proliferation of cells in a confined space during tumor growth phases; and (iii) shear stress with blood and interstitial fluid pressure. Among the physical determinants of mechanotransduction, stiffness has proved to be a major regulator of cell metabolism. Stiffness is a term used to describe the force necessary to obtain the deformation of a structure [168]. In cell biology, the stiffness of a tissue is mainly derived from ECM composition and thus the proportion of its components that are mainly represented by fibrous-forming proteins, e.g., collagens, elastin, and fibronectin (for review, [169]). Among them, hyaluronan acid and collagens are the main determinants of ECM stiffness. Information derived from ECM stiffness can then be converted by the cells and influence their fate, particularly through changes in their metabolism [170]. One remarkable feature of cancer cells is the capacity to change their metabolism to adapt to the harsh conditions of their specific tumor environment and adapt to the aberrant signaling induced by oncogenes or tumor suppressors [171]. Thus, there is a complex dialogue between the cancer cells and the tumor microenvironment as the cells can change their composition and stiffness, and in turn, the change in stiffness can lead to changes in cancer cell metabolism.

2. The link between extracellular stiffness and cell metabolism

The modification of the rigidity of the microenvironment modifies the intracellular tension, which in turn will retroact on the rigidity of the tissue. Indeed, on stiff substrates, the integrin clusters are activated and, via their binding to talin, promote actin polymerization. This generates significant intracellular tension, which will allow the recruitment of proteins such as vinculin, which will stabilize talin and potentiate the activation of FAK (focal adhesion kinase) and Rho/Rho kinase (ROCK), leading to the maturation of focal adhesions and the assembly of stress fibers $[167,172,173]$. Once this external mechanical stimulus is propagated to the cytoskeleton, it will induce the structural modifications of membrane proteins and their translocation to the nucleus. The perception of those external physical cues and their transmission to the nucleus are determinants for proper cell function and metabolism.

- Amino acid, glucose, and lipid metabolism

The effects of ECM stiffness on glucose metabolism are mediated by several pathways, of which the YAP/TAZ and FAs are predominant (see Figure 7). As reported by Ge et al., there are several other coupling pathways inducing modifications of nutrient metabolism, which will not be described in the following (for review, see [170]). Main glucose metabolism changes induced by extracellular stiffness are represented by changes in glucose uptake by GLUT transporters, regulation of glycolysis, regulation of the pentose phosphate pathway through the PI3K-AKT pathway, and glycogen metabolism through AMPK [174-178]. Amino acid metabolism is also affected by extracellular stiffness, in particular, the modulation of proline synthesis, which is mediated by Kindlin-2 [179,180]. YAP/TAZ, through mTORC1, will also potentiate amino acid uptake, and activation of 
the PI3K/AKT pathway appears to upregulate SLC6A19 protein, promoter of amino acid uptake [181,182]. Finally, lipids are also regulated by extracellular stiffness, in particular, through SREBP1 and SREBP2, which are the main regulators of cholesterol and fatty acid synthesis [183]. Furthermore, stiffness will also regulate some cell membrane lipid receptors, such as CD36 and LDLr, as an example [184,185].

- Nucleus and cell cycle

Matrix stiffness also regulates cell growth and protein synthesis. As reported by Tilghman et al., cells on soft substrate ECM (from $150 \mathrm{~Pa}$ to $300 \mathrm{~Pa}$ ) had longer cell cycles and were metabolically less active than cells growing on high-rigidity substrates (superior to $10000 \mathrm{~Pa}$ ) [186]. In this study, cells from human long carcinoma (A549) show an increase in G1 phase and low ATP levels and protein synthesis when cultured in soft substrates, which may be explained by the entry into a stage of tumor dormancy. However, these results are not transposable to all cancer cells, some being rigidity dependent, i.e., characterized by a proportional increase in growth with stiffness and "rigidity independent" [187]. This regulation of genome expression by mechanotransduction is called "nuclear mechanotransduction", and such transduction is possible through either the cytoskeleton network that bridges the cell membrane to the nucleus or by activating secondary messengers in the cytoplasm that will secondarily translocate to the nucleus (for review, see [188]).

\section{- Mitochondria}

Mitochondrial morphology is also impacted by extracellular stiffness. In a 2017 study by Lyra-Leite et al., ECM elasticity was proven a major regulator of mitochondrial metabolism in cardiac tissues [189]. Mitochondrial respiration was highly dependent on substrate stiffness, with higher basal, maximal, and spare respiratory capacity (SRC) in highly elastic modulus culture conditions. SRC is a determining parameter of mitochondrial adaptation; ECM thus seems essential in regulating mitochondrial metabolism [112]. In bovine vascular smooth muscle cells, changes in substrate stiffness were responsible for variations in mitochondrial cluster size and TMRM intensity [190]. The mechanism through which stiffness impacts mitochondrial metabolism is still lacking understatement; however, recent studies showed that high-stiffness ECM promotes mitochondrial fusion and, at the same time, impedes fission in particular through DRP1 inhibition [191]. This is also in agreement with the study of Lyra-Leite et al., since a state of fusion is known to be responsible for better mitochondrial function $[189,192]$.

3. The link between stiffness, cancer, and resistance to anticancer therapies

During tumorigenesis, ECM undergoes significant changes [193]. Peritumoral ECM accumulation results in an intense fibrotic response, also called desmoplasia, and increased stiffness. As reported above, changes in stiffness will induce changes in cancer cell metabolism. Increased stiffness will thus promote a tumor vascular phenotype, but also epithelial-mesenchymal plasticity and tumor metastasis in different tumor models [194-196]. Matrix stiffening induces modifications of tumor vascularization, increasing angiogenesis, neovessels branching, and invasion [196]. Epithelial-mesenchymal transition (EMT) also seems to be controlled by matrix stiffness, as reported by Rice et al. Fibrotic rigidity that can be found in pancreatic cancer promotes EMT elements towards a mesenchymal phenotype, leading to paclitaxel resistance [197]. This EMT transition has been elucidated in breast cancer by Fattet et al. via a mechanoresponsive EPHA2/LYN complex that promotes breast cancer invasion and metastasis [194]. Microenvironment rigidity also seems to increase resistance to conventional cancer chemotherapies and targeted therapies in different cancer models [197-199].

It is therefore essential to have controlled stiffness models to properly model cancer resistance to therapies. Three-dimensional printing allows the large choice of bioinks and the different extrusion and crosslinking methods to precisely control the stiffness of the printed construct. As an example, alginate bioinks can be tuned to have specific mechanical properties (Young's modulus and degradation rate) that will drive the differentiation 
of MSCs towards osteogenesis or adipogenesis [200]. In 2021, Kuzucu et al. were able to mimic the graded stiffness architecture that can be found in tissues by using bioinks composed of carboxylated agarose [201]. Regarding cancer research, Monferrer et al. showed that mixing GelMa and different concentrations of AlgMa allowed the creation of gradients of stiffness that highlighted the role of intercellular space stiffness on the clinical behavior of neuroblastoma [202].

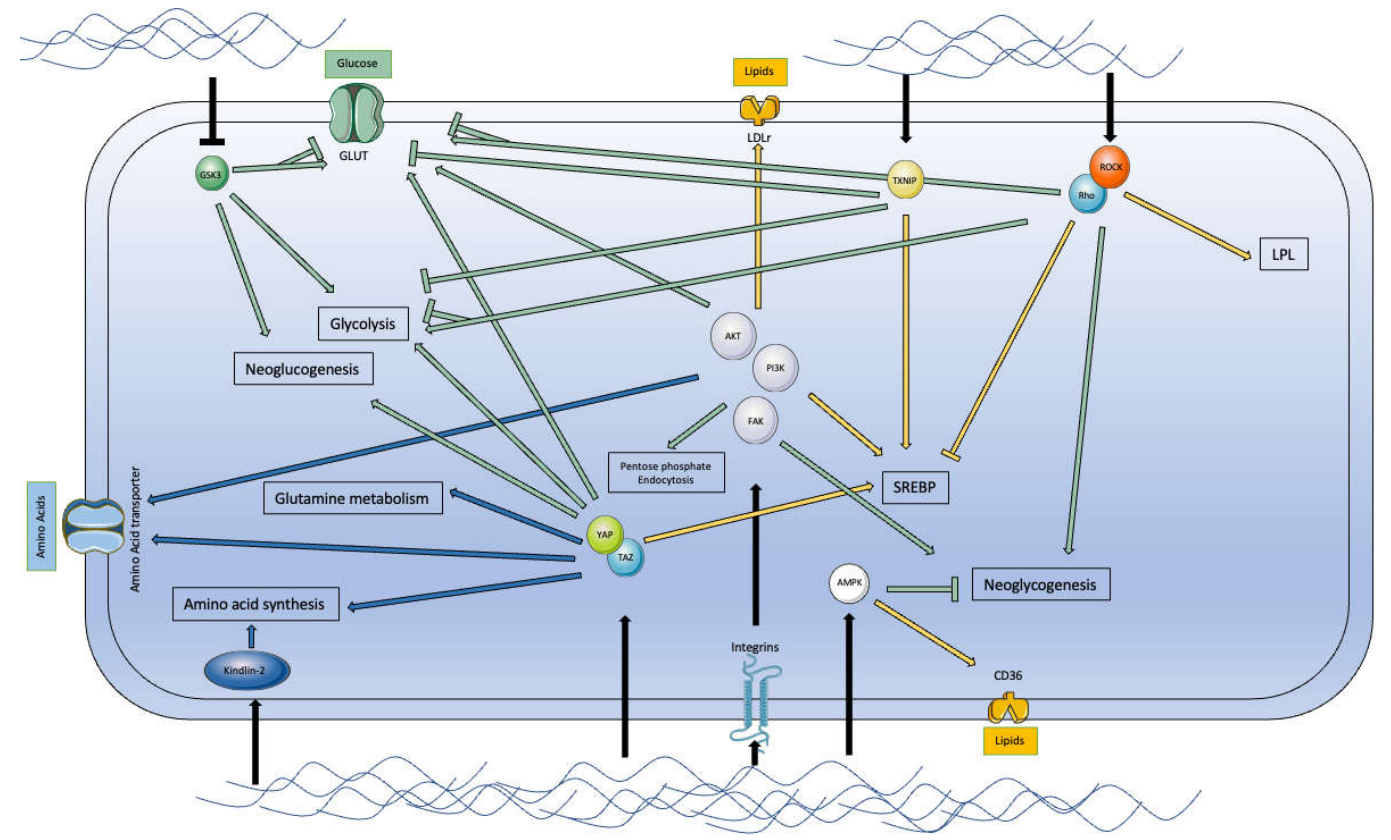

Figure 7: Main mechanotransduction pathways. In the green influence of mechanotransduction in glucose metabolism; in blue, influence in amino acid metabolism; in yellow, influence in lipid metabolism. GSK3: glycogen synthase kinase-3, GLUT: glucose transporter, LDLr: low-density lipoprotein receptor, TXNIP: Thioredoxin interacting protein, ROCK: Rho-associated protein kinase, LPL: lipoprotein lipase, PI3K: Phosphoinositide 3-kinase, FAK: focal adhesion kinase, YAP: Yes-associated protein, AMPK: AMP-activated protein kinase, SREBP: Sterol regulatory element-binding proteins, CD36: cluster of differentiation 36, also known as platelet glycoprotein 4, fatty acid translocase (FAT).

\section{b. 3D bioprinting for drug delivery and screening}

In developing new drugs, in vitro studies are essential before moving on to preclinical studies. Even if preliminary high-throughput drug screening is nowadays mostly completed on 2D cultures, simple 3D-bioprinted models could increase the relevance of this first screening while allowing for the speed and reproducibility required at this stage, which would improve the relevance of target candidates [203]. Once drug candidates have been selected, 3D bioprinting allows fabricating more complex pathologic models (organon-a-chip), narrowing the gap between initial in vitro studies and final animal testing (for review, see [204]).

Many models have already been developed; Mao et al. used patient-derived cholangiocarcinoma cells to print a 3D-bioprinted construct to test sorafenib, cisplatin, and 5fluorouracil resistance [29]. They showed that bioprinted cholangiocarcinoma cells showed stem-like properties and high resistance to all of those drugs compared to the 2D culture. Lee et al. used a fibrin-based bioink to allow glioblastoma cells to form spheroids within the construct and with an altered response to novel glioblastoma treatment methods [52]. Breast cancer 3D bioprinted models (MCF10A and MDA-MB-231 cells) have been extensively used (for review, see [205]). Breast cancer cell resistance is altered in 3D models compared to 2D models with a notably increased resistance to tamoxifen.

Apart from drug-testing platforms, 3D-printed biomaterials may also be used as drug-delivery vehicles [206]. Alginate-based drug-delivery hydrogels have been used for 
breast, prostate, and colon cancer to enhance efficiency, in particular, through local delivery, sustained action, and enhanced uptake activity [24]. In skin, 3D bioprinting allows creating personalized drug-loaded patches to deliver salicylic acid for acne treatment [207]. Bioprinting also allows the coating of microneedles to allow precise cisplatin delivery in skin cancer.

The emergence of new technologies, such as direct-volumetric drop-on-demand (DVDOD) bioprinting, will allow high-throughput drug-delivery models that will use bioprinting as a personalized drug-delivery platform [208].

\section{Conclusion}

Three-dimensional bioprinting in the past few years has made outstanding progress to become a major translational tool. Bioprinting has allowed for the fabrication of many constructs for tissue engineering and spheroid/organoid models or complex constructs for oncology. To find the most appropriate treatment for each patient, it is possible to bioprint or generate live tumor spheroids [209]. It will then be possible to find the right combination of treatments and the required dose for each patient in a personalized and precise manner. The generation of these models from patient biopsies makes them an optimal preclinical model for cancer drug screening. The creation of a biobank for each type of cancer in a 3D model will make it possible to obtain results that are more reliable and closer to clinical data than the results previously obtained from 2D models, where treatment doses are often underestimated. However, the need to print and use the constructs extemporaneously without the possibility to preserve the printed constructs remains a major limitation. The recent publication of Ravanbakhsh's team has developed a new method of cryoprinting and cryopreservation of cell-laden tissue constructs to overcome this problem [210].

The different technologies presented in this review allow us to re-create living tissues with ECM, vascularization, physical constraints, and metabolic activity, reducing the gap with in vivo studies. However, more step needs to be assessed to spread 3D bioprinting in all research teams, such as (i) the creation of standard printing guidelines, (ii) global harmonization in bioink formulations, (iii) the production of novel biomaterials with enhanced biological and physical properties, (iv) the improvement of post-printing processes and maturation of the printed construct, and (iv) the development of biological tests that can be conducted within the printed construct. The maturation of the 3D construct, also called $4 \mathrm{D}$ bioprinting (as it adds the time dimension), is one of the major issues in the years to come to allow the post-maturation of the 3D construct over time thanks to an external stimulus [211].

In this review, we highlight some major points in the bioprinting process, underlining the pros and cons of the different bioprinting technologies, bioinks, and crosslinking parameters to enable cancer researchers to make informed choices that will allow them to easily implement bioprinting in their laboratories.

Author Contributions: Writing - original draft preparation, N.G. and M.D.; writing - review and editing, N.G., M.D., S.D., and P.M. All authors have read and agreed to the published version of the manuscript.

Funding: This work is supported by the Interreg France-Wallonie-Vlaanderen programme and European Regional Development Fund (ERDF) under MAT(T)ISSE project and by a grant from Contrat de Plan Etat-Région CPER Cancer 2015-2020. N.G. is supported by fundings from the GIP Cancéropôle Nord Ouest. P.M. is supported by fundings from La Ligue Contre le Cancer, comité de l'Aisne.

Conflicts of Interest: The authors declare no conflicts of interest. 


\section{References}

1. Huang, S. H.; Liu, P.; Mokasdar, A.; Hou, L. Additive Manufacturing and Its Societal Impact: A Literature Review. Int J Adv Manuf Technology 2013, 67 (5-8), 1191-1203. https://doi.org/10.1007/s00170-012-4558-5.

2. Ho, C. M. B.; Ng, S. H.; Yoon, Y.-J. A Review on 3D Printed Bioimplants. Int J Precis Eng Man 2015, 16 (5), $1035-1046$. https://doi.org/10.1007/s12541-015-0134-x.

3. Diment, L. E.; Thompson, M. S.; Bergmann, J. H. M. Clinical Efficacy and Effectiveness of 3D Printing: A Systematic Review. Bmj Open 2017, 7 (12), e016891. https://doi.org/10.1136/bmjopen-2017-016891.

4. Belhouideg, S. Impact of 3D Printed Medical Equipment on the Management of the Covid19 Pandemic. Int J Heal Plan Management 2020, 35 (5), 1014-1022. https://doi.org/10.1002/hpm.3009.

5. Yan, Q.; Dong, H.; Su, J.; Han, J.; Song, B.; Wei, Q.; Shi, Y. A Review of 3D Printing Technology for Medical Applications. Engineering-london 2018, 4 (5), 729-742. https://doi.org/10.1016/j.eng.2018.07.021.

6. Nuseir, A.; Hatamleh, M. M.; Alnazzawi, A.; Al-Rabab'ah, M.; Kamel, B.; Jaradat, E. Direct 3D Printing of Flexible Nasal Prosthesis: Optimized Digital Workflow from Scan to Fit. J Prosthodont 2019, 28 (1), 10-14. https://doi.org/10.1111/jopr.13001.

7. Faglin, P.; Gradwohl, M.; Depoortere, C.; Germain, N.; Drucbert, A.-S.; Brun, S.; Nahon, C.; Dekiouk, S.; Rech, A.; Azaroual, N.; et al. Rationale for the Design of 3D-Printable Bioresorbable Tissue-Engineering Chambers to Promote the Growth of Adipose Tissue. Sci Rep-uk 2020, 10 (1), 11779. https://doi.org/10.1038/s41598-020-68776-8.

8. Wang, X.; Ao, Q.; Tian, X.; Fan, J.; Wei, Y.; Hou, W.; Tong, H.; Bai, S. 3D Bioprinting Technologies for Hard Tissue and Organ Engineering. Materials 2016, 9 (10), 802. https://doi.org/10.3390/ma9100802.

9. Groll, J.; Burdick, J. A.; Cho, D.-W.; Derby, B.; Gelinsky, M.; Heilshorn, S. C.; Jüngst, T.; Malda, J.; Mironov, V. A.; Nakayama, K.; et al. A Definition of Bioinks and Their Distinction from Biomaterial Inks. Biofabrication 2018,11 (1), 013001. https://doi.org/10.1088/1758-5090/aaec52.

10. Murphy, S. V.; Coppi, P. D.; Atala, A. Opportunities and Challenges of Translational 3D Bioprinting. Nat Biomed Eng 2020, 4 (4), 370-380. https://doi.org/10.1038/s41551-019-0471-7.

11. Boland, T.; Mironov, V.; Gutowska, A.; Roth, Elisabeth. A.; Markwald, R. R. Cell and Organ Printing 2: Fusion of Cell Aggregates in Three-dimensional Gels. Anatomical Rec Part Discov Mol Cell Evol Biology 2003, 272A (2), 497-502. https://doi.org/10.1002/ar.a.10059.

12. Wang, M.; Li, W.; Mille, L. S.; Ching, T.; Luo, Z.; Tang, G.; Garciamendez, C. E.; Lesha, A.; Hashimoto, M.; Zhang, Y. S. Digital Light Processing Based Bioprinting with Composable Gradients. Adv Mater 2022, $34 \quad$ (1), 2107038. https://doi.org/10.1002/adma.202107038.

13. Panwar, A.; Tan, L. P. Current Status of Bioinks for Micro-Extrusion-Based 3D Bioprinting. Molecules 2016,21 (6), 685. https://doi.org/10.3390/molecules21060685.

14. Gungor-Ozkerim, P. S.; Inci, I.; Zhang, Y. S.; Khademhosseini, A.; Dokmeci, M. R. Bioinks for 3D Bioprinting: An Overview. Biomater Sci-uk 2018, 6 (5), 915-946. https://doi.org/10.1039/c7bm00765e.

15. Gopinathan, J.; Noh, I. Recent Trends in Bioinks for 3D Printing. Biomaterials Res 2018, 22 (1), 11. https://doi.org/10.1186/s40824018-0122-1.

16. Das, S.; Basu, B. An Overview of Hydrogel-Based Bioinks for 3D Bioprinting of Soft Tissues. J Indian I Sci 2019, 99 (3), $405-428$. https://doi.org/10.1007/s41745-019-00129-5.

17. GhavamiNejad, A.; Ashammakhi, N.; Wu, X. Y.; Khademhosseini, A. Crosslinking Strategies for 3D Bioprinting of Polymeric Hydrogels. Small 2020, 16 (35), 2002931. https://doi.org/10.1002/smll.202002931.

18. Axpe, E.; Oyen, M. L. Applications of Alginate-Based Bioinks in 3D Bioprinting. Int J Mol Sci 2016,17 (12), 1976. https://doi.org/10.3390/ijms17121976.

19. Schmid, R.; Schmidt, S. K.; Hazur, J.; Detsch, R.; Maurer, E.; Boccaccini, A. R.; Hauptstein, J.; Teßmar, J.; Blunk, T.; Schrüfer, S.; et al. Comparison of Hydrogels for the Development of Well-Defined 3D Cancer Models of Breast Cancer and Melanoma. Cancers 2020, 12 (8), 2320. https://doi.org/10.3390/cancers12082320.

20. Qiao, S.; Zhao, Y.; Li, C.; Yin, Y.; Meng, Q.; Lin, F.-H.; Liu, Y.; Hou, X.; Guo, K.; Chen, X.; et al. An Alginate-Based Platform for Cancer Stem Cell Research. Acta Biomater 2016, 37, 83-92. https://doi.org/10.1016/j.actbio.2016.04.032.

21. Piras, C. C.; Smith, D. K. Multicomponent Polysaccharide Alginate-Based Bioinks. J Mater Chem B 2020, 8 (36), $8171-8188$. https://doi.org/10.1039/d0tb01005g.

22. Jiang, T.; Munguia-Lopez, J. G.; Gu, K.; Bavoux, M. M.; Flores-Torres, S.; Kort-Mascort, J.; Grant, J.; Vijayakumar, S.; LeonRodriguez, A. D.; Ehrlicher, A. J.; et al. Engineering Bioprintable Alginate/Gelatin Composite Hydrogels with Tunable Mechanical and Cell Adhesive Properties to Modulate Tumor Spheroid Growth Kinetics. Biofabrication 2020,12 (1), 015024. https://doi.org/10.1088/1758-5090/ab3a5c.

23. Reig-Vano, B.; Tylkowski, B.; Montané, X.; Giamberini, M. Alginate-Based Hydrogels for Cancer Therapy and Research. Int J Biol Macromol 2020, 170, 424-436. https://doi.org/10.1016/j.ijbiomac.2020.12.161.

24. Abasalizadeh, F.; Moghaddam, S. V.; Alizadeh, E.; akbari, E.; Kashani, E.; Fazljou, S. M. B.; Torbati, M.; Akbarzadeh, A. AlginateBased Hydrogels as Drug Delivery Vehicles in Cancer Treatment and Their Applications in Wound Dressing and 3D Bioprinting. J Biol Eng 2020, 14 (1), 8. https://doi.org/10.1186/s13036-020-0227-7.

25. Ying, G.; Jiang, N.; Yu, C.; Zhang, Y. S. Three-Dimensional Bioprinting of Gelatin Methacryloyl (GelMA). Bio-design Manuf 2018, 1 (4), 215-224. https://doi.org/10.1007/s42242-018-0028-8. 
26. He, H.; Li, D.; Lin, Z.; Peng, L.; Yang, J.; Wu, M.; Cheng, D.; Pan, H.; Ruan, C. Temperature-Programmable and Enzymatically Solidifiable Gelatin-Based Bioinks Enable Facile Extrusion Bioprinting. Biofabrication 2020, 12 (4), 045003. https://doi.org/10.1088/1758-5090/ab9906.

27. Rajabi, N.; Rezaei, A.; Kharaziha, M.; Bakhsheshi-Rad, H. R.; Luo, H.; RamaKrishna, S.; Berto, F. Recent Advances on Bioprinted Gelatin Methacrylate-Based Hydrogels for Tissue Repair. Tissue Eng Pt A 2021, 27 (11-12), 679-702. https://doi.org/10.1089/ten.tea.2020.0350.

28. Yue, K.; Santiago, G. T.; Alvarez, M. M.; Tamayol, A.; Annabi, N.; Khademhosseini, A. Synthesis, Properties, and Biomedical Applications of Gelatin Methacryloyl (GelMA) Hydrogels. Biomaterials 2015, 73, 254-271. https://doi.org/10.1016/j.biomaterials.2015.08.045.

29. Mao, S.; He, J.; Zhao, Y.; Liu, T.; Xie, F.; Yang, H.; Mao, Y.; Pang, Y.; Sun, W. Bioprinting of Patient-Derived in Vitro Intrahepatic Cholangiocarcinoma Tumor Model: Establishment, Evaluation and Anti-Cancer Drug Testing. Biofabrication 2020, 12 (4), 045014. https://doi.org/10.1088/1758-5090/aba0c3.

30. Miranda, M. A.; Marcato, P. D.; Mondal, A.; Chowdhury, N.; Gebeyehu, A.; Surapaneni, S. K.; Bentley, M. V. L. B.; Amaral, R.; Pan, C.-X.; Singh, M. Cytotoxic and Chemosensitizing Effects of Glycoalkaloidic Extract on 2D and 3D Models Using RT4 and Patient Derived Xenografts Bladder Cancer Cells. Mater Sci Eng C 2021, 119, 111460. https://doi.org/10.1016/j.msec.2020.111460.

31. Piras, C. C.; Fernández-Prieto, S.; Borggraeve, W. M. D. Nanocellulosic Materials as Bioinks for 3D Bioprinting. Biomater Sci-uk 2017, 5 (10), 1988-1992. https://doi.org/10.1039/c7bm00510e.

32. Wang, X.; Wang, Q.; Xu, C. Nanocellulose-Based Inks for 3D Bioprinting: Key Aspects in Research Development and Challenging Perspectives in Applications-A Mini Review. Bioeng 2020, 7 (2), 40. https://doi.org/10.3390/bioengineering7020040.

33. Kim, J.; Jang, J.; Cho, D.-W. Controlling Cancer Cell Behavior by Improving the Stiffness of Gastric Tissue-Decellularized ECM Bioink With Cellulose Nanoparticles. Frontiers Bioeng Biotechnology 2021, 9, 605819. https://doi.org/10.3389/fbioe.2021.605819.

34. Gospodinova, A.; Nankov, V.; Tomov, S.; Redzheb, M.; Petrov, P. D. Extrusion Bioprinting of Hydroxyethylcellulose-Based Bioink for Cervical Tumor Model. Carbohyd Polym 2021, 260, 117793. https://doi.org/10.1016/j.carbpol.2021.117793.

35. Olmos-Juste, R.; Alonso-Lerma, B.; Pérez-Jiménez, R.; Gabilondo, N.; Eceiza, A. 3D Printed Alginate-Cellulose Nanofibers Based Patches for Local Curcumin Administration. Carbohyd Polym 2021, 264, 118026. https://doi.org/10.1016/j.carbpol.2021.118026.

36. Stefano, P. D.; Briatico-Vangosa, F.; Bianchi, E.; Pellegata, A. F.; Hartungen, A. H. de; Corti, P.; Dubini, G. Bioprinting of Matrigel Scaffolds for Cancer Research. Polymers-basel 2021, 13 (12), 2026. https://doi.org/10.3390/polym13122026.

37. Fan, R.; Piou, M.; Darling, E.; Cormier, D.; Sun, J.; Wan, J. Bio-Printing Cell-Laden Matrigel-Agarose Constructs. J Biomater Appl 2016, 31 (5), 684-692. https://doi.org/10.1177/0885328216669238.

38. Snyder, J. E.; Hamid, Q.; Wang, C.; Chang, R.; Emami, K.; Wu, H.; Sun, W. Bioprinting Cell-Laden Matrigel for Radioprotection Study of Liver by pro-Drug Conversion in a Dual-Tissue Microfluidic Chip. Biofabrication 2011, 3 (3), 034112. https://doi.org/10.1088/1758-5082/3/3/034112.

39. Horváth, L.; Umehara, Y.; Jud, C.; Blank, F.; Petri-Fink, A.; Rothen-Rutishauser, B. Engineering an in Vitro Air-Blood Barrier by 3D Bioprinting. Sci Rep-uk 2015, 5 (1), 7974. https://doi.org/10.1038/srep07974.

40. Benton, G.; Kleinman, H. K.; George, J.; Arnaoutova, I. Multiple Uses of Basement Membrane-like Matrix (BME/Matrigel) in Vitro and in Vivo with Cancer Cells. Int J Cancer 2011, 128 (8), 1751-1757. https://doi.org/10.1002/ijc.25781.

41. Osidak, E. O.; Kozhukhov, V. I.; Osidak, M. S.; Domogatsky, S. P. Collagen as Bioink for Bioprinting: A Comprehensive Review. Int J Bioprinting 2020, 6 (3), 270. https://doi.org/10.18063/ijb.v6i3.270.

42. Swaminathan, S.; Hamid, Q.; Sun, W.; Clyne, A. M. Bioprinting of 3D Breast Epithelial Spheroids for Human Cancer Models. Biofabrication 2019, 11 (2), 025003. https://doi.org/10.1088/1758-5090/aafc49.

43. Marques, C. F.; Diogo, G. S.; Pina, S.; Oliveira, J. M.; Silva, T. H.; Reis, R. L. Collagen-Based Bioinks for Hard Tissue Engineering Applications: A Comprehensive Review. J Mater Sci Mater Medicine 2019, 30 (3), 32. https://doi.org/10.1007/s10856-019-6234-x.

44. Campos, D. F. D.; Marquez, A. B.; O’Seanain, C.; Fischer, H.; Blaeser, A.; Vogt, M.; Corallo, D.; Aveic, S. Exploring Cancer Cell Behavior In Vitro in Three-Dimensional Multicellular Bioprintable Collagen-Based Hydrogels. Cancers 2019,11 (2), 180. https://doi.org/10.3390/cancers11020180.

45. Noh, I.; Kim, N.; Tran, H. N.; Lee, J.; Lee, C. 3D Printable Hyaluronic Acid-Based Hydrogel for Its Potential Application as a Bioink in Tissue Engineering. Biomaterials Res 2019, 23 (1), 3. https://doi.org/10.1186/s40824-018-0152-8.

46. Schmid, R.; Schmidt, S. K.; Detsch, R.; Horder, H.; Blunk, T.; Schrüfer, S.; Schubert, D. W.; Fischer, L.; Thievessen, I.; HeltmannMeyer, S.; et al. A New Printable Alginate/Hyaluronic Acid/Gelatin Hydrogel Suitable for Biofabrication of In Vitro and In Vivo Metastatic Melanoma Models. Adv Funct Mater 2021, 2107993. https://doi.org/10.1002/adfm.202107993.

47. Petta, D.; DAmora, U.; Ambrosio, L.; Grijpma, D. W.; Eglin, D.; DEste, M. Hyaluronic Acid as a Bioink for Extrusion-Based 3D Printing. Biofabrication 2020, 12 (3), 032001. https://doi.org/10.1088/1758-5090/ab8752.

48. Horder, H.; Lasheras, M. G.; Grummel, N.; Nadernezhad, A.; Herbig, J.; Ergün, S.; Teßmar, J.; Groll, J.; Fabry, B.; Bauer-Kreisel, P.; et al. Bioprinting and Differentiation of Adipose-Derived Stromal Cell Spheroids for a 3D Breast Cancer-Adipose Tissue Model. Cells 2021, 10 (4), 803. https://doi.org/10.3390/cells10040803.

49. López-Marcial, G. R.; Zeng, A. Y.; Osuna, C.; Dennis, J.; García, J. M.; O’Connell, G. D. Agarose-Based Hydrogels as Suitable Bioprinting Materials for Tissue Engineering. Acs Biomater Sci Eng 2018, 4 (10), 3610-3616. https://doi.org/10.1021/acsbiomaterials.8b00903.

50. Kim, J. E.; Kim, S. H.; Jung, Y. Current Status of Three-Dimensional Printing Inks for Soft Tissue Regeneration. Tissue Eng Regen Med 2016, 13 (6), 636-646. https://doi.org/10.1007/s13770-016-0125-8. 
51. Abelseth, E.; Abelseth, L.; Vega, L. D. la; Beyer, S. T.; Wadsworth, S. J.; Willerth, S. M. 3D Printing of Neural Tissues Derived from Human Induced Pluripotent Stem Cells Using a Fibrin-Based Bioink. Acs Biomater Sci Eng 2019, 5 (1), $234-243$. https://doi.org/10.1021/acsbiomaterials.8b01235.

52. Lee, C.; Abelseth, E.; Vega, L. de la; Willerth, S. M. Bioprinting a Novel Glioblastoma Tumor Model Using a Fibrin-Based Bioink for Drug Screening. Mater Today Chem 2019, 12, 78-84. https://doi.org/10.1016/j.mtchem.2018.12.005.

53. Sharma, R.; Smits, I. P. M.; Vega, L. D. L.; Lee, C.; Willerth, S. M. 3D Bioprinting Pluripotent Stem Cell Derived Neural Tissues Using a Novel Fibrin Bioink Containing Drug Releasing Microspheres. Frontiers Bioeng Biotechnology 2020, $8,57$. https://doi.org/10.3389/fbioe.2020.00057.

54. Chawla, S.; Midha, S.; Sharma, A.; Ghosh, S. Silk-Based Bioinks for 3D Bioprinting. Adv Healthc Mater 2018, 7 (8), 1701204. https://doi.org/10.1002/adhm.201701204.

55. Gangrade, A.; Mandal, B. B. Drug Delivery of Anticancer Drugs from Injectable 3D Porous Silk Scaffold for Prevention of Gastric Cancer Growth and Recurrence. Acs Biomater Sci Eng 2020, 6 (11), 6195-6206. https://doi.org/10.1021/acsbiomaterials.0c01043.

56. Qian, K.-Y.; Song, Y.; Yan, X.; Dong, L.; Xue, J.; Xu, Y.; Wang, B.; Cao, B.; Hou, Q.; Peng, W.; et al. Injectable Ferrimagnetic Silk Fibroin Hydrogel for Magnetic Hyperthermia Ablation of Deep Tumor. Biomaterials 2020, 259, 120299. https://doi.org/10.1016/j.biomaterials.2020.120299.

57. Wang, Q.; Han, G.; Yan, S.; Zhang, Q. 3D Printing of Silk Fibroin for Biomedical Applications. Mater Basel Switz 2019,12 (3), 504. https://doi.org/10.3390/ma12030504.

58. Pitarresi, G.; Martorana, A.; Palumbo, F. S.; Fiorica, C.; Giammona, G. New Gellan Gum-Graft-Poly(d,l-Lactide-Co-Glycolide) Copolymers as Promising Bioinks: Synthesis and Characterization. Int J Biol Macromol 2020, 162, $1653-1667$. https://doi.org/10.1016/j.ijbiomac.2020.07.254.

59. Zhu, S.; Yao, L.; Pan, C.; Tian, J.; Li, L.; Luo, B.; Zhou, C.; Lu, L. 3D Printed Gellan Gum/Graphene Oxide Scaffold for Tumor Therapy and Bone Reconstruction. Compos Sci Technol 2021, 208, 108763. https://doi.org/10.1016/j.compscitech.2021.108763.

60. Lozano, R.; Stevens, L.; Thompson, B. C.; Gilmore, K. J.; Gorkin, R.; Stewart, E. M.; Panhuis, M. in het; Romero-Ortega, M.; Wallace, G. G. 3D Printing of Layered Brain-like Structures Using Peptide Modified Gellan Gum Substrates. Biomaterials 2015, 67, 264-273. https://doi.org/10.1016/j.biomaterials.2015.07.022.

61. Tonda-Turo, C.; Carmagnola, I.; Chiappone, A.; Feng, Z.; Ciardelli, G.; Hakkarainen, M.; Sangermano, M. Photocurable Chitosan as Bioink for Cellularized Therapies towards Personalized Scaffold Architecture. Bioprinting 2020, 18, e00082. https://doi.org/10.1016/j.bprint.2020.e00082.

62. Babu, A.; Ramesh, R. Multifaceted Applications of Chitosan in Cancer Drug Delivery and Therapy. Mar Drugs 2017, 15 (4), 96. https://doi.org/10.3390/md15040096.

63. Sahranavard, M.; Zamanian, A.; Ghorbani, F.; Shahrezaee, M. H. A Critical Review on Three Dimensional-Printed Chitosan Hydrogels for Development of Tissue Engineering. Bioprinting 2020, 17, e00063. https://doi.org/10.1016/j.bprint.2019.e00063.

64. Roth, A. D.; Lama, P.; Dunn, S.; Hong, S.; Lee, M.-Y. Polymer Coating on a Micropillar Chip for Robust Attachment of PuraMatrix Peptide Hydrogel for 3D Hepatic Cell Culture. Mater Sci Eng C Mater Biological Appl 2018, 90, 634-644. https://doi.org/10.1016/j.msec.2018.04.092.

65. Yang, Z.; Xu, H.; Zhao, X. Designer Self-Assembling Peptide Hydrogels to Engineer 3D Cell Microenvironments for Cell Constructs Formation and Precise Oncology Remodeling in Ovarian Cancer. Adv Sci Weinheim Baden-wurttemberg Ger 2020, 7 (9), 1903718. https://doi.org/10.1002/advs.201903718.

66. Pati, F.; Jang, J.; Ha, D.-H.; Kim, S. W.; Rhie, J.-W.; Shim, J.-H.; Kim, D.-H.; Cho, D.-W. Printing Three-Dimensional Tissue Analogues with Decellularized Extracellular Matrix Bioink. Nat Commun 2014, 5 (1), 3935. https://doi.org/10.1038/ncomms4935.

67. Ferreira, L. P.; Gaspar, V. M.; Mano, J. F. Decellularized Extracellular Matrix for Bioengineering Physiomimetic 3D in Vitro Tumor Models. Trends Biotechnol 2020, 38 (12), 1397-1414. https://doi.org/10.1016/j.tibtech.2020.04.006.

68. Jang, J.; Park, H.-J.; Kim, S.-W.; Kim, H.; Park, J. Y.; Na, S. J.; Kim, H. J.; Park, M. N.; Choi, S. H.; Park, S. H.; et al. 3D Printed Complex Tissue Construct Using Stem Cell-Laden Decellularized Extracellular Matrix Bioinks for Cardiac Repair. Biomaterials 2017, 112, 264-274. https://doi.org/10.1016/j.biomaterials.2016.10.026.

69. Hwang, J.; San, B. H.; Turner, N. J.; White, L. J.; Faulk, D. M.; Badylak, S. F.; Li, Y.; Yu, S. M. Molecular Assessment of Collagen Denaturation in Decellularized Tissues Using a Collagen Hybridizing Peptide. Acta Biomater 2017, 53, $268-278$. https://doi.org/10.1016/j.actbio.2017.01.079.

70. He, Y.; Wang, F.; Wang, X.; Zhang, J.; Wang, D.; Huang, X. A Photocurable Hybrid Chitosan/Acrylamide Bioink for DLP Based 3D Bioprinting. Mater Design 2021, 202, 109588. https://doi.org/10.1016/j.matdes.2021.109588.

71. Poellmann, M. J.; Johnson, A. J. W. Multimaterial Polyacrylamide: Fabrication with Electrohydrodynamic Jet Printing, Applications, and Modeling. Biofabrication 2014, 6 (3), 035018. https://doi.org/10.1088/1758-5082/6/3/035018.

72. Poh, P. S. P.; Hutmacher, D. W.; Stevens, M. M.; Woodruff, M. A. Fabrication and in Vitro Characterization of Bioactive Glass Composite Scaffolds for Bone Regeneration. Biofabrication 2013, 5 (4), 045005. https://doi.org/10.1088/1758-5082/5/4/045005.

73. Kundu, J.; Shim, J.-H.; Jang, J.; Kim, S.-W.; Cho, D.-W. An Additive Manufacturing-Based PCL-Alginate-Chondrocyte Bioprinted Scaffold for Cartilage Tissue Engineering. J Tissue Eng Regen M 2013, 9 (11), $1286-1297$. https://doi.org/10.1002/term.1682.

74. Zamani, Y.; Mohammadi, J.; Amoabediny, G.; Helder, M. N.; Zandieh-Doulabi, B.; Klein-Nulend, J. Bioprinting of AlginateEncapsulated Pre-Osteoblasts in PLGA/ $\beta$-TCP Scaffolds Enhances Cell Retention but Impairs Osteogenic Differentiation Compared to Cell Seeding after 3D-Printing. Regen Eng Transl Medicine 2021, 7 (4), 485-493. https://doi.org/10.1007/s40883-020-001631. 
75. Abelardo, E. 3D Bioprinting for Reconstructive Surgery. 2018, 137-144. https://doi.org/10.1016/b978-0-08-101103-4.00009-0.

76. Zhu, J. Bioactive Modification of Poly(Ethylene Glycol) Hydrogels for Tissue Engineering. Biomaterials 2010, 31 (17), $4639-4656$. https://doi.org/10.1016/j.biomaterials.2010.02.044.

77. Hong, S.; Sycks, D.; Chan, H. F.; Lin, S.; Lopez, G. P.; Guilak, F.; Leong, K. W.; Zhao, X. 3D Printing of Highly Stretchable and Tough Hydrogels into Complex, Cellularized Structures. Adv Mater 2015, 27 (27), 4035-4040. https://doi.org/10.1002/adma.201501099.

78. Müller, M.; Becher, J.; Schnabelrauch, M.; Zenobi-Wong, M. Nanostructured Pluronic Hydrogels as Bioinks for 3D Bioprinting. Biofabrication 2015, 7 (3), 035006. https://doi.org/10.1088/1758-5090/7/3/035006.

79. Gioffredi, E.; Boffito, M.; Calzone, S.; Giannitelli, S. M.; Rainer, A.; Trombetta, M.; Mozetic, P.; Chiono, V. Pluronic F127 Hydrogel Characterization and Biofabrication in Cellularized Constructs for Tissue Engineering Applications. Proc Cirp 2016, 49, 125132. https://doi.org/10.1016/j.procir.2015.11.001.

80. Hsieh, F.-Y.; Lin, H.-H.; Hsu, S. 3D Bioprinting of Neural Stem Cell-Laden Thermoresponsive Biodegradable Polyurethane Hydrogel and Potential in Central Nervous System Repair. Biomaterials 2015, 71, 48-57. https://doi.org/10.1016/j.biomaterials.2015.08.028.

81. Hung, K.; Tseng, C.; Hsu, S. Synthesis and 3D Printing of Biodegradable Polyurethane Elastomer by a Water-Based Process for Cartilage Tissue Engineering Applications. Adv Healthc Mater 2014, 3 (10), 1578-1587. https://doi.org/10.1002/adhm.201400018.

82. Costa, E. C.; Moreira, A. F.; Melo-Diogo, D. de; Gaspar, V. M.; Carvalho, M. P.; Correia, I. J. 3D Tumor Spheroids: An Overview on the Tools and Techniques Used for Their Analysis. Biotechnol Adv 2016, 34 (8), 1427-1441. https://doi.org/10.1016/j.biotechadv.2016.11.002.

83. Pinto, B.; Henriques, A. C.; Silva, P. M. A.; Bousbaa, H. Three-Dimensional Spheroids as In Vitro Preclinical Models for Cancer Research. Pharm 2020, 12 (12), E1186. https://doi.org/10.3390/pharmaceutics12121186.

84. Friedrich, J.; Seidel, C.; Ebner, R.; Kunz-Schughart, L. A. Spheroid-Based Drug Screen: Considerations and Practical Approach. Nat Protoc 2009, 4 (3), 309-324. https://doi.org/10.1038/nprot.2008.226.

85. Zanoni, M.; Piccinini, F.; Arienti, C.; Zamagni, A.; Santi, S.; Polico, R.; Bevilacqua, A.; Tesei, A. 3D Tumor Spheroid Models for in Vitro Therapeutic Screening: A Systematic Approach to Enhance the Biological Relevance of Data Obtained. Sci Rep-uk 2016, 6 (1), 19103. https://doi.org/10.1038/srep19103.

86. Ma, H.; Jiang, Q.; Han, S.; Wu, Y.; Tomshine, J. C.; Wang, D.; Gan, Y.; Zou, G.; Liang, X.-J. Multicellular Tumor Spheroids as an in Vivo-Like Tumor Model for Three-Dimensional Imaging of Chemotherapeutic and Nano Material Cellular Penetration. Mol Imaging 2012, 11 (6), 7290.2012.00012. https://doi.org/10.2310/7290.2012.00012.

87. Longati, P.; Jia, X.; Eimer, J.; Wagman, A.; Witt, M.-R.; Rehnmark, S.; Verbeke, C.; Toftgård, R.; Löhr, M.; Heuchel, R. L. 3D Pancreatic Carcinoma Spheroids Induce a Matrix-Rich, Chemoresistant Phenotype Offering a Better Model for Drug Testing. Bmc Cancer 2013, 13 (1), 95. https://doi.org/10.1186/1471-2407-13-95.

88. Loebsack, A. B.; Halberstadt, C. R.; Holder, W. D.; Culberson, C. R.; Beiler, R. J.; Greene, K. G.; Roland, W. D.; Burg, K. J. The Development of an Embedding Technique for Polylactide Sponges. J Biomed Mater Res 1999, 48 (4), 504-510. https://doi.org/10.1002/(sici)1097-4636(1999)48:4<504::aid-jbm16>3.0.co;2-y.

89. Ruan, J.-L.; Tulloch, N. L.; Muskheli, V.; Genova, E. E.; Mariner, P. D.; Anseth, K. S.; Murry, C. E. An Improved Cryosection Method for Polyethylene Glycol Hydrogels Used in Tissue Engineering. Tissue Eng Part C Methods 2013,19 (10), $794-801$. https://doi.org/10.1089/ten.tec.2012.0460.

90. James, R.; Jenkins, L.; Ellis, S. E.; Burg, K. J. L. Histological Processing of Hydrogel Scaffolds for Tissue-Engineering Applications. J Histotechnol 2004, 27 (2), 133-139. https://doi.org/10.1179/his.2004.27.2.133.

91. Béduer, A.; Piacentini, N.; Aeberli, L.; Silva, A. D.; Verheyen, C. A.; Bonini, F.; Rochat, A.; Filippova, A.; Serex, L.; Renaud, P.; et al. Additive Manufacturing of Hierarchical Injectable Scaffolds for Tissue Engineering. Acta Biomater 2018, 76, 71-79. https://doi.org/10.1016/j.actbio.2018.05.056.

92. Huisken, J.; Swoger, J.; Bene, F. D.; Wittbrodt, J.; Stelzer, E. H. K. Optical Sectioning Deep Inside Live Embryos by Selective Plane Illumination Microscopy. Science 2004, 305 (5686), 1007-1009. https://doi.org/10.1126/science.1100035.

93. Schneckenburger, H.; Weber, P.; Wagner, M.; Schickinger, S.; Richter, V.; Bruns, T.; Strauss, W. s. 1.; Wittig, R. Light Exposure and Cell Viability in Fluorescence Microscopy. J Microsc-oxford 2012, 245 (3), 311-318. https://doi.org/10.1111/j.13652818.2011.03576.x.

94. Smyrek, I.; Stelzer, E. H. K. Quantitative Three-Dimensional Evaluation of Immunofluorescence Staining for Large Whole Mount Spheroids with Light Sheet Microscopy. Biomed Opt Express 2017, 8 (2), 484-499. https://doi.org/10.1364/boe.8.000484.

95. Lazzari, G.; Vinciguerra, D.; Balasso, A.; Nicolas, V.; Goudin, N.; Garfa-Traore, M.; Fehér, A.; Dinnyés, A.; Nicolas, J.; Couvreur, P.; et al. Light Sheet Fluorescence Microscopy versus Confocal Microscopy: In Quest of a Suitable Tool to Assess Drug and Nanomedicine Penetration into Multicellular Tumor Spheroids. Eur J Pharm Biopharm 2019, 142, $195-203$. https://doi.org/10.1016/j.ejpb.2019.06.019.

96. Yu, F.; Han, X.; Zhang, K.; Dai, B.; Shen, S.; Gao, X.; Teng, H.; Wang, X.; Li, L.; Ju, H.; et al. Evaluation of a Polyvinyl AlcoholAlginate Based Hydrogel for Precise 3D Bioprinting. J Biomed Mater Res A 2018, 106 (11), $2944-2954$. https://doi.org/10.1002/jbm.a.36483.

97. Li, X.; Chen, S.; Li, J.; Wang, X.; Zhang, J.; Kawazoe, N.; Chen, G. 3D Culture of Chondrocytes in Gelatin Hydrogels with Different Stiffness. Polymers-basel 2016, 8 (8), 269. https://doi.org/10.3390/polym8080269. 
98. Cambria, E.; Brunner, S.; Heusser, S.; Fisch, P.; Hitzl, W.; Ferguson, S. J.; Wuertz-Kozak, K. Cell-Laden Agarose-Collagen Composite Hydrogels for Mechanotransduction Studies. Frontiers Bioeng Biotechnology 2020, 8, 346. https://doi.org/10.3389/fbioe.2020.00346.

99. Norberg, K. J.; Liu, X.; Moro, C. F.; Strell, C.; Nania, S.; Blümel, M.; Balboni, A.; Bozóky, B.; Heuchel, R. L.; Löhr, J. M. A Novel Pancreatic Tumour and Stellate Cell 3D Co-Culture Spheroid Model. Bmc Cancer 2020, 20 (1), 475. https://doi.org/10.1186/s12885020-06867-5.

100. Hassan, W.; Dong, Y.; Wang, W. Encapsulation and 3D Culture of Human Adipose-Derived Stem Cells in an in-Situ Crosslinked Hybrid Hydrogel Composed of PEG-Based Hyperbranched Copolymer and Hyaluronic Acid. Stem Cell Res Ther 2013, 4 (2), 32. https://doi.org/10.1186/scrt182.

101. Chen, H.; Fei, F.; Li, X.; Nie, Z.; Zhou, D.; Liu, L.; Zhang, J.; Zhang, H.; Fei, Z.; Xu, T. A Facile, Versatile Hydrogel Bioink for 3D Bioprinting Benefits Long-Term Subaqueous Fidelity, Cell Viability and Proliferation. Regen Biomaterials 2021, 8 (3), rbab026. https://doi.org/10.1093/rb/rbab026.

102. Sbrana, F. V.; Pinos, R.; Barbaglio, F.; Ribezzi, D.; Scagnoli, F.; Scarfò, L.; Redwan, I. N.; Martinez, H.; Farè, S.; Ghia, P.; et al. 3D Bioprinting Allows the Establishment of Long-Term 3D Culture Model for Chronic Lymphocytic Leukemia Cells. Front Immunol 2021, 12, 639572. https://doi.org/10.3389/fimmu.2021.639572.

103. Khattak, S. F.; Spatara, M.; Roberts, L.; Roberts, S. C. Application of Colorimetric Assays to Assess Viability, Growth and Metabolism of Hydrogel-Encapsulated Cells. Biotechnol Lett 2006, 28 (17), 1361-1370. https://doi.org/10.1007/s10529-006-9104-9.

104. Polley, C.; Mau, R.; Lieberwirth, C.; Stenzel, J.; Vollmar, B.; Seitz, H. Bioprinting of Three Dimensional Tumor Models: A Preliminary Study Using a Low Cost 3D Printer. Curr Dir Biomed Eng 2017, 3 (2), 135-138. https://doi.org/10.1515/cdbme-2017-0028.

105. Ho, W. Y.; Yeap, S. K.; Ho, C. L.; Rahim, R. A.; Alitheen, N. B. Development of Multicellular Tumor Spheroid (MCTS) Culture from Breast Cancer Cell and a High Throughput Screening Method Using the MTT Assay. Plos One 2012, 7 (9), e44640. https://doi.org/10.1371/journal.pone.0044640.

106. Maloney, E.; Clark, C.; Sivakumar, H.; Yoo, K.; Aleman, J.; Rajan, S. A. P.; Forsythe, S.; Mazzocchi, A.; Laxton, A. W.; Tatter, S. B.; et al. Immersion Bioprinting of Tumor Organoids in Multi-Well Plates for Increasing Chemotherapy Screening Throughput. Micromachines-basel 2020, 11 (2), 208. https://doi.org/10.3390/mi11020208.

107. Germain, N.; Dhayer, M.; Boileau, M.; Fovez, Q.; Kluza, J.; Marchetti, P. Lipid Metabolism and Resistance to Anticancer Treatment. Biology 2020, 9 (12), E474. https://doi.org/10.3390/biology9120474.

108. Marchetti, P.; Guerreschi, P.; Mortier, L.; Kluza, J. Integration of Mitochondrial Targeting for Molecular Cancer Therapeutics. Int J Cell Biology 2015, 2015, 283145. https://doi.org/10.1155/2015/283145.

109. Tondera, C.; Hauser, S.; Krüger-Genge, A.; Jung, F.; Neffe, A. T.; Lendlein, A.; Klopfleisch, R.; Steinbach, J.; Neuber, C.; Pietzsch, J. Gelatin-Based Hydrogel Degradation and Tissue Interaction in Vivo: Insights from Multimodal Preclinical Imaging in Immunocompetent Nude Mice. Theranostics 2016, 6 (12), 2114-2128. https://doi.org/10.7150/thno.16614.

110. Noel, P.; Muñoz, R.; Rogers, G. W.; Neilson, A.; Hoff, D. D. V.; Han, H. Preparation and Metabolic Assay of 3-Dimensional Spheroid Co-Cultures of Pancreatic Cancer Cells and Fibroblasts. J Vis Exp Jove 2017, No. 126, e56081. https://doi.org/10.3791/56081.

111. Hsieh, F.-Y.; Tao, L.; Wei, Y.; Hsu, S. A Novel Biodegradable Self-Healing Hydrogel to Induce Blood Capillary Formation. Npg Asia Mater 2017, 9 (3), e363-e363. https://doi.org/10.1038/am.2017.23.

112. Marchetti, P.; Fovez, Q.; Germain, N.; Khamari, R.; Kluza, J. Mitochondrial Spare Respiratory Capacity: Mechanisms, Regulation, and Significance in Non-Transformed and Cancer Cells. Faseb J 2020, 34 (10), 13106-13124. https://doi.org/10.1096/fj.202000767r.

113. Hunnewell, M.; Forbes, N. S. Active and Inactive Metabolic Pathways in Tumor Spheroids: Determination by GC-MS. Biotechnol Progr 2010, 26 (3), 789-796. https://doi.org/10.1002/btpr.360.

114. Forbes, N. S.; Meadows, A. L.; Clark, D. S.; Blanch, H. W. Estradiol Stimulates the Biosynthetic Pathways of Breast Cancer Cells: Detection by Metabolic Flux Analysis. Metab Eng 2006, 8 (6), 639-652. https://doi.org/10.1016/j.ymben.2006.06.005.

115. Kim, B.; Forbes, N. S. Flux Analysis Shows That Hypoxia-Inducible-Factor-1-Alpha Minimally Affects Intracellular Metabolism in Tumor Spheroids. Biotechnol Bioeng 2007, 96 (6), 1167-1182. https://doi.org/10.1002/bit.21205.

116. Klapa, M. I.; Aon, J.-C.; Stephanopoulos, G. Ion-Trap Mass Spectrometry Used in Combination with Gas Chromatography for High-Resolution Metabolic Flux Determination. Biotechniques 2003, 34 (4), 832-836, 838, 840 passim. https://doi.org/10.2144/03344pt02.

117. Ewa-Choy, Y. W.; Pingguan-Murphy, B.; Abdul-Ghani, N. A.; Jahendran, J.; Chua, K. H. Effect of Alginate Concentration on Chondrogenesis of Co-Cultured Human Adipose-Derived Stem Cells and Nasal Chondrocytes: A Biological Study. Biomaterials Res 2017, 21 (1), 19. https://doi.org/10.1186/s40824-017-0105-7.

118. Li, X.; Chen, Y.; Kawazoe, N.; Chen, G. Influence of Microporous Gelatin Hydrogels on Chondrocyte Functions. J Mater Chem B 2017, 5 (29), 5753-5762. https://doi.org/10.1039/c7tb01350g.

119. Meinert, C.; Schrobback, K.; Hutmacher, D. W.; Klein, T. J. A Novel Bioreactor System for Biaxial Mechanical Loading Enhances the Properties of Tissue-Engineered Human Cartilage. Sci Rep-uk 2017, 7 (1), 16997. https://doi.org/10.1038/s41598-017-16523-x.

120. Park, H.; Temenoff, J. S.; Tabata, Y.; Caplan, A. I.; Mikos, A. G. Injectable Biodegradable Hydrogel Composites for Rabbit Marrow Mesenchymal Stem Cell and Growth Factor Delivery for Cartilage Tissue Engineering. Biomaterials 2007, 28 (21), $3217-3227$. https://doi.org/10.1016/j.biomaterials.2007.03.030. 
121. Haugh, M. G.; Meyer, E. G.; Thorpe, S. D.; Vinardell, T.; Duffy, G. P.; Kelly, D. J. Temporal and Spatial Changes in CartilageMatrix-Specific Gene Expression in Mesenchymal Stem Cells in Response to Dynamic Compression. Tissue Eng Pt A 2011, 17 (23-24), 3085-3093. https://doi.org/10.1089/ten.tea.2011.0198.

122. Gauch, S.; Hermann, R.; Feuser, P.; Oelmüller, U.; Bastian, H. Isolation of Total RNA Using Silica-Gel Based Membranes. In Molecular Tools for Screening Biodiversity: Plants and Animals; ["Karp, Isaac, Angela and, Ingram, Peter G. and, S."], David, Eds.; Springer Netherlands: Dordrecht, 1998; pp 67-70. https://doi.org/10.1007/978-94-009-0019-6_16.

123. Köster, N.; Schmiermund, A.; Grubelnig, S.; Leber, J.; Ehlicke, F.; Czermak, P.; Salzig, D. Single-Step RNA Extraction from Different Hydrogel-Embedded Mesenchymal Stem Cells for Quantitative Reverse Transcription-Polymerase Chain Reaction Analysis. Tissue Eng Part C Methods 2016, 22 (6), 552-560. https://doi.org/10.1089/ten.tec.2015.0362.

124. Bougault, C.; Paumier, A.; Aubert-Foucher, E.; Mallein-Gerin, F. Investigating Conversion of Mechanical Force into Biochemical Signaling in Three-Dimensional Chondrocyte Cultures. Nat Protoc 2009, 4 (6), 928-938. https://doi.org/10.1038/nprot.2009.63.

125. Shin, D.-S.; You, J.; Rahimian, A.; Vu, T.; Siltanen, C.; Ehsanipour, A.; Stybayeva, G.; Sutcliffe, J.; Revzin, A. Photodegradable Hydrogels for Capture, Detection, and Release of Live Cells. Angewandte Chemie Int Ed 2014, 53 (31), 8221-8224. https://doi.org/10.1002/anie.201404323.

126. Friedrich, J.; Eder, W.; Castaneda, J.; Doss, M.; Huber, E.; Ebner, R.; Kunz-Schughart, L. A. A Reliable Tool to Determine Cell Viability in Complex 3-D Culture: The Acid Phosphatase Assay. J Biomol Screen 2007, 12 (7), 925-937. https://doi.org/10.1177/1087057107306839.

127. Beaumont, K. A.; Anfosso, A.; Ahmed, F.; Weninger, W.; Haass, N. K. Imaging- and Flow Cytometry-Based Analysis of Cell Position and the Cell Cycle in 3D Melanoma Spheroids. J Vis Exp 2015, No. 106, 53486. https://doi.org/10.3791/53486.

128. Geng, Z.; Zhang, H.; Xiong, Q.; Zhang, Y.; Zhao, H.; Wang, G. A Fluorescent Chitosan Hydrogel Detection Platform for the Sensitive and Selective Determination of Trace Mercury( Ii ) in Water. J Mater Chem A 2015, 3 (38), 19455-19460. https://doi.org/10.1039/c5ta05610a.

129. Muir, A.; Danai, L. V.; Heiden, M. G. V. Microenvironmental Regulation of Cancer Cell Metabolism: Implications for Experimental Design and Translational Studies. Dis Model Mech 2018, 11 (8), dmm035758. https://doi.org/10.1242/dmm.035758.

130. Mueller, M. M.; Fusenig, N. E. Friends or Foes - Bipolar Effects of the Tumour Stroma in Cancer. Nat Rev Cancer 2004, 4 (11), 839-849. https://doi.org/10.1038/nrc1477.

131. Hanahan, D.; Coussens, L. M. Accessories to the Crime: Functions of Cells Recruited to the Tumor Microenvironment. Cancer Cell 2012, 21 (3), 309-322. https://doi.org/10.1016/j.ccr.2012.02.022.

132. Duong, M. N.; Geneste, A.; Fallone, F.; Li, X.; Dumontet, C.; Muller, C. The Fat and the Bad: Mature Adipocytes, Key Actors in Tumor Progression and Resistance. Oncotarget 2017, 8 (34), 57622-57641. https://doi.org/10.18632/oncotarget.18038.

133. Zhao, C.; Wu, M.; Zeng, N.; Xiong, M.; Hu, W.; Lv, W.; Yi, Y.; Zhang, Q.; Wu, Y. Cancer-Associated Adipocytes: Emerging Supporters in Breast Cancer. J Exp Clin Cancer Res Cr 2020, 39 (1), 156. https://doi.org/10.1186/s13046-020-01666-z.

134. Sahai, E.; Astsaturov, I.; Cukierman, E.; DeNardo, D. G.; Egeblad, M.; Evans, R. M.; Fearon, D.; Greten, F. R.; Hingorani, S. R.; Hunter, T.; et al. A Framework for Advancing Our Understanding of Cancer-Associated Fibroblasts. Nat Rev Cancer 2020, 20 (3), 174-186. https://doi.org/10.1038/s41568-019-0238-1.

135. Fiori, M. E.; Franco, S. D.; Villanova, L.; Bianca, P.; Stassi, G.; Maria, R. D. Cancer-Associated Fibroblasts as Abettors of Tumor Progression at the Crossroads of EMT and Therapy Resistance. Mol Cancer 2019, 18 (1), 70. https://doi.org/10.1186/s12943-0190994-2.

136. Hanley, C. J.; Thomas, G. J. T-Cell Tumour Exclusion and Immunotherapy Resistance: A Role for CAF Targeting. Brit J Cancer 2020, 123 (9), 1353-1355. https://doi.org/10.1038/s41416-020-1020-6.

137. Mondal, A.; Gebeyehu, A.; Miranda, M.; Bahadur, D.; Patel, N.; Ramakrishnan, S.; Rishi, A. K.; Singh, M. Characterization and Printability of Sodium Alginate -Gelatin Hydrogel for Bioprinting NSCLC Co-Culture. Sci Rep-uk 2019, 9 (1), 19914. https://doi.org/10.1038/s41598-019-55034-9.

138. Datta, P.; Dey, M.; Ataie, Z.; Unutmaz, D.; Ozbolat, I. T. 3D Bioprinting for Reconstituting the Cancer Microenvironment. Npj Precis Oncol 2020, 4 (1), 18. https://doi.org/10.1038/s41698-020-0121-2.

139. Luo, Y.; Wei, X.; Huang, P. 3D Bioprinting of Hydrogel-based Biomimetic Microenvironments. J Biomed Mater Res Part B Appl Biomaterials 2019, 107 (5), 1695-1705. https://doi.org/10.1002/jbm.b.34262.

140. Samadian, H.; Jafari, S.; Sepand, M. R.; Alaei, L.; Malvajerd, S. S.; Jaymand, M.; Ghobadinezhad, F.; Jahanshahi, F.; Hamblin, M. R.; Derakhshankhah, H.; et al. 3D Bioprinting Technology to Mimic the Tumor Microenvironment: Tumor-on-a-Chip Concept. Mater Today Adv 2021, 12, 100160. https://doi.org/10.1016/j.mtadv.2021.100160.

141. Albritton, J. L.; Miller, J. S. 3D Bioprinting: Improving in Vitro Models of Metastasis with Heterogeneous Tumor Microenvironments. Dis Model Mech 2017, 10 (1), 3-14. https://doi.org/10.1242/dmm.025049.

142. Richards, D.; Jia, J.; Yost, M.; Markwald, R.; Mei, Y. 3D Bioprinting for Vascularized Tissue Fabrication. Ann Biomed Eng 2017, 45 (1), 132-147. https://doi.org/10.1007/s10439-016-1653-z.

143. Rajabi, M.; Mousa, S. A. The Role of Angiogenesis in Cancer Treatment. Biomed 2017, 5 (2), 34. https://doi.org/10.3390/biomedicines5020034.

144. Liao, D.; Johnson, R. S. Hypoxia: A Key Regulator of Angiogenesis in Cancer. Cancer Metast Rev 2007, 26 (2), $281-290$. https://doi.org/10.1007/s10555-007-9066-y.

145. Zervantonakis, I. K.; Hughes-Alford, S. K.; Charest, J. L.; Condeelis, J. S.; Gertler, F. B.; Kamm, R. D. Three-Dimensional Microfluidic Model for Tumor Cell Intravasation and Endothelial Barrier Function. Proc National Acad Sci 2012, 109 (34), 13515-13520. https://doi.org/10.1073/pnas.1210182109. 
146. Meng, F.; Meyer, C. M.; Joung, D.; Vallera, D. A.; McAlpine, M. C.; Panoskaltsis-Mortari, A. 3D Bioprinted In Vitro Metastatic Models via Reconstruction of Tumor Microenvironments. Adv Mater 2019, $31 \quad(10)$, 1806899. https://doi.org/10.1002/adma.201806899.

147. Chaffer, C. L.; Weinberg, R. A. A Perspective on Cancer Cell Metastasis. Science 2011, 331 (6024), $1559-1564$. https://doi.org/10.1126/science.1203543.

148. Guy, J.-B.; Espenel, S.; Vallard, A.; Battiston-Montagne, P.; Wozny, A.-S.; Ardail, D.; Alphonse, G.; Rancoule, C.; RodriguezLafrasse, C.; Magne, N. Evaluation of the Cell Invasion and Migration Process: A Comparison of the Video Microscope-Based Scratch Wound Assay and the Boyden Chamber Assay. J Vis Exp 2017, No. 129. https://doi.org/10.3791/56337.

149. Jung, M.; Skhinas, J. N.; Du, E. Y.; Tolentino, M. A. K.; Utama, R. H.; Engel, M.; Volkerling, A.; Sexton, A.; O’Mahony, A. P.; Ribeiro, J. C. C.; et al. A High-Throughput 3D Bioprinted Cancer Cell Migration and Invasion Model with Versatile and Broad Biological Applicability. Biorxiv 2021, 2021.12.28.474387. https://doi.org/10.1101/2021.12.28.474387.

150. Li, Y.; Wang, Z.; Ajani, J. A.; Song, S. Drug Resistance and Cancer Stem Cells. Cell Commun Signal 2021,19 (1), 19. https://doi.org/10.1186/s12964-020-00627-5.

151. Seo, E. J.; Kim, D. K.; Jang, I. H.; Choi, E. J.; Shin, S. H.; Lee, S. I.; Kwon, S.-M.; Kim, K.-H.; Suh, D.-S.; Kim, J. H. HypoxiaNOTCH1-SOX2 Signaling Is Important for Maintaining Cancer Stem Cells in Ovarian Cancer. Oncotarget 2016, 7 (34), 5562455638. https://doi.org/10.18632/oncotarget.10954.

152. Ishiguro, T.; Ohata, H.; Sato, A.; Yamawaki, K.; Enomoto, T.; Okamoto, K. Tumor-derived Spheroids: Relevance to Cancer Stem Cells and Clinical Applications. Cancer Sci 2017, 108 (3), 283-289. https://doi.org/10.1111/cas.13155.

153. Guo, X.; Chen, Y.; Ji, W.; Chen, X.; Li, C.; Ge, R. Enrichment of Cancer Stem Cells by Agarose Multi-Well Dishes and 3D Spheroid Culture. Cell Tissue Res 2019, 375 (2), 397-408. https://doi.org/10.1007/s00441-018-2920-0.

154. Suzuka, J.; Tsuda, M.; Wang, L.; Kohsaka, S.; Kishida, K.; Semba, S.; Sugino, H.; Aburatani, S.; Frauenlob, M.; Kurokawa, T.; et al. Rapid Reprogramming of Tumour Cells into Cancer Stem Cells on Double-Network Hydrogels. Nat Biomed Eng 2021, 5 (8), 914-925. https://doi.org/10.1038/s41551-021-00692-2.

155. Xu, X.; Liu, C.; Liu, Y.; Yang, L.; Li, N.; Guo, X.; Sun, G.; Ma, X. Enrichment of Cancer Stem Cell-like Cells by Culture in Alginate Gel Beads. J Biotechnol 2014, 177, 1-12. https://doi.org/10.1016/j.jbiotec.2014.02.016.

156. Moore, C. A.; Siddiqui, Z.; Carney, G. J.; Naaldijk, Y.; Guiro, K.; Ferrer, A. I.; Sherman, L. S.; Guvendiren, M.; Kumar, V. A.; Rameshwar, P. A 3D Bioprinted Material That Recapitulates the Perivascular Bone Marrow Structure for Sustained Hematopoietic and Cancer Models. Polymers-basel 2021, 13 (4), 480. https://doi.org/10.3390/polym13040480.

157. Florczyk, S. J.; Kievit, F. M.; Wang, K.; Erickson, A. E.; Ellenbogen, R. G.; Zhang, M. 3D Porous Chitosan-Alginate Scaffolds Promote Proliferation and Enrichment of Cancer Stem-like Cells. J Mater Chem B 2016, 4 (38), 6326-6334. https://doi.org/10.1039/c6tb01713d.

158. Kievit, F. M.; Florczyk, S. J.; Leung, M. C.; Wang, K.; Wu, J. D.; Silber, J. R.; Ellenbogen, R. G.; Lee, J. S. H.; Zhang, M. Proliferation and Enrichment of CD133+ Glioblastoma Cancer Stem Cells on 3D Chitosan-Alginate Scaffolds. Biomaterials 2014, 35 (33), $9137-$ 9143. https://doi.org/10.1016/j.biomaterials.2014.07.037.

159. Chen, L.; Xiao, Z.; Meng, Y.; Zhao, Y.; Han, J.; Su, G.; Chen, B.; Dai, J. The Enhancement of Cancer Stem Cell Properties of MCF7 Cells in 3D Collagen Scaffolds for Modeling of Cancer and Anti-Cancer Drugs. Biomaterials 2012, 33 (5), $1437-1444$. https://doi.org/10.1016/j.biomaterials.2011.10.056.

160. Wang, X.; Dai, X.; Zhang, X.; Li, X.; Xu, T.; Lan, Q. Enrichment of Glioma Stem Cell-like Cells on 3D Porous Scaffolds Composed of Different Extracellular Matrix. Biochem Bioph Res Co 2018, 498 (4), 1052-1057. https://doi.org/10.1016/j.bbrc.2018.03.114.

161. Qiao, S.; Zhao, Y.; Li, C.; Yin, Y.; Meng, Q.; Lin, F.-H.; Liu, Y.; Hou, X.; Guo, K.; Chen, X.; et al. An Alginate-Based Platform for Cancer Stem Cell Research. Acta Biomater 2016, 37, 83-92. https://doi.org/10.1016/j.actbio.2016.04.032.

162. Feng, S.; Duan, X.; Lo, P.-K.; Liu, S.; Liu, X.; Chen, H.; Wang, Q. Expansion of Breast Cancer Stem Cells with Fibrous Scaffolds. Integr Biol 2013, 5 (5), 768-777. https://doi.org/10.1039/c3ib20255k.

163. Chen, C. S. Mechanotransduction - a Field Pulling Together? J Cell Sci 2008, 121 (20), $3285-3292$. https://doi.org/10.1242/jcs.023507.

164. Kulangara, K.; Leong, K. W. Substrate Topography Shapes Cell Function. Soft Matter 2009, 5 (21), $4072-4076$. https://doi.org/10.1039/b910132m.

165. Ghibaudo, M.; Saez, A.; Trichet, L.; Xayaphoummine, A.; Browaeys, J.; Silberzan, P.; Buguin, A.; Ladoux, B. Traction Forces and Rigidity Sensing Regulate Cell Functions. Soft Matter 2008, 4 (9), 1836-1843. https://doi.org/10.1039/b804103b.

166. Orr, A. W.; Helmke, B. P.; Blackman, B. R.; Schwartz, M. A. Mechanisms of Mechanotransduction. Dev Cell 2006, 10 (1), 11-20. https://doi.org/10.1016/j.devcel.2005.12.006.

167. Geiger, B.; Spatz, J. P.; Bershadsky, A. D. Environmental Sensing through Focal Adhesions. Nat Rev Mol Cell Bio 2009, 10 (1), 2133. https://doi.org/10.1038/nrm2593.

168. Baumgart, F. Stiffness - an Unknown World of Mechanical Science? Inj 2000, 31, 14-84. https://doi.org/10.1016/s00201383(00)80040-6.

169. Theocharis, A. D.; Skandalis, S. S.; Gialeli, C.; Karamanos, N. K. Extracellular Matrix Structure. Adv Drug Deliver Rev 2016, 97, 4-27. https://doi.org/10.1016/j.addr.2015.11.001.

170. Ge, H.; Tian, M.; Pei, Q.; Tan, F.; Pei, H. Extracellular Matrix Stiffness: New Areas Affecting Cell Metabolism. Frontiers Oncol 2021, 11, 631991. https://doi.org/10.3389/fonc.2021.631991. 
171. Strickaert, A.; Saiselet, M.; Dom, G.; Deken, X. D.; Dumont, J. E.; Feron, O.; Sonveaux, P.; Maenhaut, C. Cancer Heterogeneity Is Not Compatible with One Unique Cancer Cell Metabolic Map. Oncogene 2017, 36 (19), $2637-2642$. https://doi.org/10.1038/onc.2016.411.

172. Martino, F.; Perestrelo, A. R.; Vinarský, V.; Pagliari, S.; Forte, G. Cellular Mechanotransduction: From Tension to Function. Front Physiol 2018, 9, 824. https://doi.org/10.3389/fphys.2018.00824.

173. Butcher, D. T.; Alliston, T.; Weaver, V. M. A Tense Situation: Forcing Tumour Progression. Nat Rev Cancer 2009, 9 (2), 108-122. https://doi.org/10.1038/nrc2544.

174. Cox, A. G.; Tsomides, A.; Yimlamai, D.; Hwang, K. L.; Miesfeld, J.; Galli, G. G.; Fowl, B. H.; Fort, M.; Ma, K. Y.; Sullivan, M. R.; et al. Yap Regulates Glucose Utilization and Sustains Nucleotide Synthesis to Enable Organ Growth. Embo J 2018, 37 (22). https://doi.org/10.15252/embj.2018100294.

175. Liu, Q.; Song, G. Matrix Stiffness Promotes Hepatoma Cell Glycolysis and Migration Through YAP-Mediated Mechanotransduction. Mol Cell Biomech 2019, 16 (S2), 127-127. https://doi.org/10.32604/mcb.2019.07105.

176. Bays, J. L.; Campbell, H. K.; Heidema, C.; Sebbagh, M.; DeMali, K. A. Linking E-Cadherin Mechanotransduction to Cell Metabolism through Force-Mediated Activation of AMPK. Nat Cell Biol 2017, 19 (6), 724-731. https://doi.org/10.1038/ncb3537.

177. Jiang, P.; Du, W.; Wu, M. Regulation of the Pentose Phosphate Pathway in Cancer. Protein Cell 2014, 5 (8), $592-602$. https://doi.org/10.1007/s13238-014-0082-8.

178. Hardie, D. G.; Ross, F. A.; Hawley, S. A. AMPK: A Nutrient and Energy Sensor That Maintains Energy Homeostasis. Nat Rev Mol Cell Bio 2012, 13 (4), 251-262. https://doi.org/10.1038/nrm3311.

179. Guo, L.; Cui, C.; Zhang, K.; Wang, J.; Wang, Y.; Lu, Y.; Chen, K.; Yuan, J.; Xiao, G.; Tang, B.; et al. Kindlin-2 Links MechanoEnvironment to Proline Synthesis and Tumor Growth. Nat Commun 2019, 10 (1), 845. https://doi.org/10.1038/s41467-019-087723.

180. Chen, K.; Guo, L.; Wu, C. How Signaling Pathways Link Extracellular Mechano-environment to Proline Biosynthesis: A Hypothesis. Bioessays 2021, 2100116. https://doi.org/10.1002/bies.202100116.

181. Bogatikov, E.; Munoz, C.; Pakladok, T.; Alesutan, I.; Shojaiefard, M.; Seebohm, G.; Föller, M.; Palmada, M.; Böhmer, C.; Bröer, S.; et al. Up-Regulation of Amino Acid Transporter SLC6A19 Activity and Surface Protein Abundance by PKB/Akt and PIKfyve. Cell Physiol Biochem 2012, 30 (6), 1538-1546. https://doi.org/10.1159/000343341.

182. Hansen, C. G.; Ng, Y. L. D.; Lam, W.-L. M.; Plouffe, S. W.; Guan, K.-L. The Hippo Pathway Effectors YAP and TAZ Promote Cell Growth by Modulating Amino Acid Signaling to MTORC1. Cell Res 2015, 25 (12), $1299-1313$. https://doi.org/10.1038/cr.2015.140.

183. Romani, P.; Brian, I.; Santinon, G.; Pocaterra, A.; Audano, M.; Pedretti, S.; Mathieu, S.; Forcato, M.; Bicciato, S.; Manneville, J.B.; et al. Extracellular Matrix Mechanical Cues Regulate Lipid Metabolism through Lipin-1 and SREBP. Nat Cell Biol 2019, 21 (3), 338-347. https://doi.org/10.1038/s41556-018-0270-5.

184. Luiken, J. J. F. P.; Coort, S. L. M.; Willems, J.; Coumans, W. A.; Bonen, A.; Vusse, G. J. van der; Glatz, J. F. C. Contraction-Induced Fatty Acid Translocase/CD36 Translocation in Rat Cardiac Myocytes Is Mediated Through AMP-Activated Protein Kinase Signaling. Diabetes 2003, 52 (7), 1627-1634. https://doi.org/10.2337/diabetes.52.7.1627.

185. Edinger, A. L.; Thompson, C. B. Akt Maintains Cell Size and Survival by Increasing MTOR-Dependent Nutrient Uptake. Mol Biol Cell 2002, 13 (7), 2276-2288. https://doi.org/10.1091/mbc.01-12-0584.

186. Tilghman, R. W.; Blais, E. M.; Cowan, C. R.; Sherman, N. E.; Grigera, P. R.; Jeffery, E. D.; Fox, J. W.; Blackman, B. R.; Tschumperlin, D. J.; Papin, J. A.; et al. Matrix Rigidity Regulates Cancer Cell Growth by Modulating Cellular Metabolism and Protein Synthesis. Plos One 2012, 7 (5), e37231. https://doi.org/10.1371/journal.pone.0037231.

187. Tilghman, R. W.; Cowan, C. R.; Mih, J. D.; Koryakina, Y.; Gioeli, D.; Slack-Davis, J. K.; Blackman, B. R.; Tschumperlin, D. J.; Parsons, J. T. Matrix Rigidity Regulates Cancer Cell Growth and Cellular Phenotype. Plos One 2010, 5 (9), e12905. https://doi.org/10.1371/journal.pone.0012905.

188. Uhler, C.; Shivashankar, G. V. Regulation of Genome Organization and Gene Expression by Nuclear Mechanotransduction. Nat Rev Mol Cell Bio 2017, 18 (12), 717-727. https://doi.org/10.1038/nrm.2017.101.

189. Lyra-Leite, D. M.; Andres, A. M.; Petersen, A. P.; Ariyasinghe, N. R.; Cho, N.; Lee, J. A.; Gottlieb, R. A.; McCain, M. L. Mitochondrial Function in Engineered Cardiac Tissues Is Regulated by Extracellular Matrix Elasticity and Tissue Alignment. Am J Physiol-heart C 2017, 313 (4), H757-H767. https://doi.org/10.1152/ajpheart.00290.2017.

190. Bartolák-Suki, E.; Imsirovic, J.; Nishibori, Y.; Krishnan, R.; Suki, B. Regulation of Mitochondrial Structure and Dynamics by the Cytoskeleton and Mechanical Factors. Int J Mol Sci 2017, 18 (8), 1812. https://doi.org/10.3390/ijms18081812.

191. Chen, K.; Wang, Y.; Deng, X.; Guo, L.; Wu, C. Extracellular Matrix Stiffness Regulates Mitochondrial Dynamics through PINCH1- and Kindlin-2-Mediated Signalling. Curr Res Cell Biology 2021, 2, 100008. https://doi.org/10.1016/j.crcbio.2021.100008.

192. Westermann, B. Bioenergetic Role of Mitochondrial Fusion and Fission. Biochimica Et Biophysica Acta Bba - Bioenergetics 2012, 1817 (10), 1833-1838. https://doi.org/10.1016/j.bbabio.2012.02.033.

193. Gkretsi, V.; Stylianopoulos, T. Cell Adhesion and Matrix Stiffness: Coordinating Cancer Cell Invasion and Metastasis. Frontiers Oncol 2018, 8, 145. https://doi.org/10.3389/fonc.2018.00145.

194. Fattet, L.; Jung, H.-Y.; Matsumoto, M. W.; Aubol, B. E.; Kumar, A.; Adams, J. A.; Chen, A. C.; Sah, R. L.; Engler, A. J.; Pasquale, E. B.; et al. Matrix Rigidity Controls Epithelial-Mesenchymal Plasticity and Tumor Metastasis via a Mechanoresponsive EPHA2/LYN Complex. Dev Cell 2020, 54 (3), 302-316.e7. https://doi.org/10.1016/j.devcel.2020.05.031.

195. Ros, M.; Sala, M.; Saltel, F. Linking Matrix Rigidity with EMT and Cancer Invasion. Dev Cell 2020, 54 (3), $293-295$. https://doi.org/10.1016/j.devcel.2020.06.032. 
196. Bordeleau, F.; Mason, B. N.; Lollis, E. M.; Mazzola, M.; Zanotelli, M. R.; Somasegar, S.; Califano, J. P.; Montague, C.; LaValley, D. J.; Huynh, J.; et al. Matrix Stiffening Promotes a Tumor Vasculature Phenotype. Proc National Acad Sci 2017, 114 (3), $492-497$. https://doi.org/10.1073/pnas.1613855114.

197. Rice, A. J.; Cortes, E.; Lachowski, D.; Cheung, B. C. H.; Karim, S. A.; Morton, J. P.; Hernández, A. del R. Matrix Stiffness Induces Epithelial-Mesenchymal Transition and Promotes Chemoresistance in Pancreatic Cancer Cells. Oncogenesis 2017, 6 (7), e352e352. https://doi.org/10.1038/oncsis.2017.54.

198. Qin, X.; Lv, X.; Li, P.; Yang, R.; Xia, Q.; Chen, Y.; Peng, Y.; Li, L.; Li, S.; Li, T.; et al. Matrix Stiffness Modulates ILK-Mediated YAP Activation to Control the Drug Resistance of Breast Cancer Cells. Biochimica Et Biophysica Acta Bba-Mol Basis Dis 2020, 1866 (3), 165625. https://doi.org/10.1016/j.bbadis.2019.165625.

199. Lin, C.-H.; Pelissier, F. A.; Zhang, H.; Lakins, J.; Weaver, V. M.; Park, C.; LaBarge, M. A. Microenvironment Rigidity Modulates Responses to the HER2 Receptor Tyrosine Kinase Inhibitor Lapatinib via YAP and TAZ Transcription Factors. Mol Biol Cell 2015, 26 (22), 3946-3953. https://doi.org/10.1091/mbc.e15-07-0456.

200. Freeman, F. E.; Kelly, D. J. Tuning Alginate Bioink Stiffness and Composition for Controlled Growth Factor Delivery and to Spatially Direct MSC Fate within Bioprinted Tissues. Sci Rep-uk 2017, 7 (1), 17042. https://doi.org/10.1038/s41598-017-17286-1.

201. Kuzucu, M.; Vera, G.; Beaumont, M.; Fischer, S.; Wei, P.; Shastri, V. P.; Forget, A. Extrusion-Based 3D Bioprinting of Gradients of Stiffness, Cell Density, and Immobilized Peptide Using Thermogelling Hydrogels. Acs Biomater Sci Eng 2021, 7 (6), $2192-2197$. https://doi.org/10.1021/acsbiomaterials.1c00183.

202. Monferrer, E.; Martín-Vañó, S.; Carretero, A.; García-Lizarribar, A.; Burgos-Panadero, R.; Navarro, S.; Samitier, J.; Noguera, R. A Three-Dimensional Bioprinted Model to Evaluate the Effect of Stiffness on Neuroblastoma Cell Cluster Dynamics and Behavior. Sci Rep-uk 2020, 10 (1), 6370. https://doi.org/10.1038/s41598-020-62986-w.

203. Mazzocchi, A.; Soker, S.; Skardal, A. 3D Bioprinting for High-Throughput Screening: Drug Screening, Disease Modeling, and Precision Medicine Applications. Appl Phys Rev 2019, 6 (1), 011302. https://doi.org/10.1063/1.5056188.

204. Ma, X.; Liu, J.; Zhu, W.; Tang, M.; Lawrence, N.; Yu, C.; Gou, M.; Chen, S. 3D Bioprinting of Functional Tissue Models for Personalized Drug Screening and in Vitro Disease Modeling. Adv Drug Deliver Rev 2018, 132, $235-251$. https://doi.org/10.1016/j.addr.2018.06.011.

205. Sharifi, M.; Bai, Q.; Babadaei, M. M. N.; Chowdhury, F.; Hasan, M.; Taghizadeh, A.; Derakhshankhah, H.; Khan, S.; Hasan, A.; Falahati, M. 3D Bioprinting of Engineered Breast Cancer Constructs for Personalized and Targeted Cancer Therapy. J Control Release 2021, 333, 91-106. https://doi.org/10.1016/j.jconrel.2021.03.026.

206. Lee, J.; Unnithan, A. R.; Park, C. H.; Kim, C. S. Biomimetic Nanoengineered Materials for Advanced Drug Delivery. 2019, No. Biofabrication 74 2015, 61-72. https://doi.org/10.1016/b978-0-12-814944-7.00005-9.

207. Bom, S.; Martins, A. M.; Ribeiro, H. M.; Marto, J. Diving into 3D (Bio)Printing: A Revolutionary Tool to Customize the Production of Drug and Cell-Based Systems for Skin Delivery. Int J Pharmaceut 2021, 605, 120794. https://doi.org/10.1016/j.ijpharm.2021.120794.

208. Grottkau, B. E.; Hui, Z.; Pang, Y. A Novel 3D Bioprinter Using Direct-Volumetric Drop-On-Demand Technology for Fabricating Micro-Tissues and Drug-Delivery. Int J Mol Sci 2020, 21 (10), 3482. https://doi.org/10.3390/ijms21103482.

209. Botti, G.; Bonito, M. D.; Cantile, M. Organoid Biobanks as a New Tool for Pre-Clinical Validation of Candidate Drug Efficacy and Safety. Int J Physiology Pathophysiol Pharmacol 2021, 13 (1), 17-21.

210. Ravanbakhsh, H.; Luo, Z.; Zhang, X.; Maharjan, S.; Mirkarimi, H. S.; Tang, G.; Chávez-Madero, C.; Mongeau, L.; Zhang, Y. S. Freeform Cell-Laden Cryobioprinting for Shelf-Ready Tissue Fabrication and Storage. Matter 2022, 5 (2), $573-593$. https://doi.org/10.1016/j.matt.2021.11.020.

211. Miri, A. K.; Khalilpour, A.; Cecen, B.; Maharjan, S.; Shin, S. R.; Khademhosseini, A. Multiscale Bioprinting of Vascularized Models. Biomaterials 2019, 198, 204-216. https://doi.org/10.1016/j.biomaterials.2018.08.006. 